Portland State University

PDXScholar

Dissertations and Theses

Dissertations and Theses

1977

\title{
Personal incidental fund: a study in policy making
}

Shirley Rackner

Portland State University

Follow this and additional works at: https://pdxscholar.library.pdx.edu/open_access_etds

Part of the Gerontology Commons, and the Social Work Commons Let us know how access to this document benefits you.

Recommended Citation

Rackner, Shirley, "Personal incidental fund: a study in policy making" (1977). Dissertations and Theses. Paper 2168.

https://doi.org/10.15760/etd.2165

This Thesis is brought to you for free and open access. It has been accepted for inclusion in Dissertations and Theses by an authorized administrator of PDXScholar. Please contact us if we can make this document more accessible: pdxscholar@pdx.edu. 
PERSONAL INCIDENTAL FUND:

A STUDY IN POLICY MAKING

by

SHIRLEY RACKNER

A practicum submitted in partial fulfillment of the requirements for the degree of

MASTER Of SOCIAL WORK

Portland State University

1977 
TO THE OFFICE OF GRADUATE STUDIES AND RESEARCH:

The advisor approves the practicum of Shirley Rackner presented May 25, 1977.

Gerald|Frey, Ph.D., Advisor 
TABLE OF CONTENTS

PAGE

LIST OF TABLES . . . . . . . . . . . . . . . v v

LIST OF FIGURES . . . . . . . . . . . . . . . vi vi

CHAPTER

I INTRODUCTION . . . . . . . . . . . . . . 1

The Federal Perspective

Statewide Interpretation

Formulating the Policy

Implementation

Methodology

I I FEDERAL HISTORY: MEDICAL

CARE PROGRAMS ............ . 10

III HISTORY OF TITLE XIX IN OREGON • • • • • . 22

IV THE PERSONAL INCIDENTAL FUND:

A CASE HISTORY . . . . . . . . . . . . 36

The First Nursing Home

Committee Meeting

The Second Nursing Home

Committee Meeting

The OHCA/PWD Meeting

Writing the Administrative

Rule

$V$ AN ANALYSIS OF THE PROCESS OF

POLICY DEVELOPMENT . . . . . . . . . . . 71

Problem Identification

The legitimation System 
VI BARRIERS TO IMPLEMENTATION :

SOME OBSERVATIONS • • • . . • . . . . 91

Division of Labor

Required Information

Interaction

Barriers to Effective Policy

Policy Formulation vs. Goals

Communication

Intra-Agency Conflict

VII CONCLUSION • . . . . . . . . . . . . 112

BIBLIOGRAPHY • • • • • • • • • • • • • • • . 117

APPENDIX . . . . . . . . . . . . . . . . . 120 


\section{LIST OF TABLES}

TABLE

PAGE

I DESCRIPTION OF COMPONENTS . . . . . . . . 92 


\section{LIST OF FIGURES}

F IGURE

PAGE

1 Changes in Existing Policy . . . . . . . . 89

2 Identification of Other Problems . . . . . 90 


\section{CHAPTER I}

\section{INTRODUCTION}

originally, the focus of this project was to be a policy analysis and survey of the new procedures and regulations established by the state of oregon for the protection and management of nursing home residents' Personal Incidental Funds (PIF). The analysis was to be divided into four phases, according to a pre-planned timetable. The last phase was to be a field survey of the policy's impact upon nursing homes and adult service workers. The timetable was synchronized with that of the Congregate Care Consultant from the Public Welfare Division's (PWD) Adult Services Unit, whose responsibility it was to develop and write a new policy for the state. Although the PIF is a miniscule segment of the total policy which the state of Oregon has developed for nursing facilities, it is submitted here as representative of public policy formulation in that area.

The Personal Incidental Fund policy contains two sections: one is concerned with residents' funds relevant to the residents' friends and relatives. 
The other section is concerned with regulations for the facilities. The release date for both sections of a new policy had been scheduled for January 1 , 1977. However, as the development of Personal Incidental Fund policy regulations concerning friends and relatives was not completed until March 1, and the policy concerning the facilities will not go into effect until July 1977, the focus of this study has become a consideration of the barriers to implementation.

During the fiscal year 1975-1976, Medicaid patients in the state of Oregon who reside in skilled nursing and intermediate care facilities received Personal Incidental Funds in the amount of $\$ 2,600,000$. These PIF monies are distributed under Title XIX of the Social Security Act. The purpose of the PIF is to enhance the daily life of the residents by providing the means to purchase needed incidental items and clothing.

Currently there are approximately 8,800

individuals in Oregon who receive these funds. These individuals vary in their ability to manage their funds. There is also great variance in the 
dependability of the staff and/or relatives, who manage the funds for residents who cannot do so themselves. (White 1976)

The 1965 federal legislation (Title XIX) included few guidelines and requirements for protection and management of these monies; as a result the state has had to interpret and write regulations, trying to preserve if not intuit the intent of the federal legislation.

\section{THE FEDERAL PERSPECTIVE}

The history of the legislation that created Title XIX is important, as it reflects the philosophical ambivalence we have as a nation about providing medical care for our citizens. The legislation in question provided care for those "catagorically needy," including the elderly. The problems facing nursing homes today were preceded by a long and difficult twelve-year period before the original protective legislation was interpreted relative to nursing facilities. The failure of the legislation to give the Department of Health, Education and Welfare immediate authority to administer the program can be seen now in the lack of uniform interpretation in every aspect of the Act. 
STATEWIDE INTERPRETATION

Oregon's perspective on the issue of Medicaid is analogous to the national history of medical care for the aged. The state has traditionally participated in national programs which were instituted to benefit their citizens; this was true of the Medicaid program of 1965, implemented throughout Oregon by the Public Welfare Department's thirty-six agencies. Under this first implementation the residents of nursing homes each received $\$ 15$ in Personal Incidental Funds (PIF). Although a sum was established by law, no regulations or procedures for administering the funds accompanied it. The evolution of the regulations to help manage and protect the residents' PIF constitutes an interesting example of piecemeal policy-making. The need for drafting comprehensive policy relevant to PIF was recognized in late 1976 . The responsibility was given to the Congregate care Consultant of the Public Welfare Division (PWD). The performance and accomplishment of this task constitutes the case history of the newly written PIF policy and procedures which this paper will discuss. 
FORMULATING THE POLICY

The Congregate care consultant may have used a conventional problem solving method:

1. Identify the problem;

2. Clarify the values and objectives;

3. List all possible ways for policies to achieve goals;

4. Investigate consequences;

5. Compare consequences;

6. Choose policy witi consequences which most closely match goals. (Lindblom 1968)

This classical policy formulation procedure seems to provide a model that any rational policy writer could use successfully. However, the PIF case history and attendant analysis demonstrates that the rational or classical policy formulation became unfeasible in actual practice.

The case history of this policy will describe the sequence of events that led to the policy's creation, revision, acceptance, and the ultimate delay in its release. Participants in the policy's formulation are noted, as are the contributions they made; it is hoped that an examination of the interactions of the participants will yield insight into the complex process of making public policy. 


\section{IMPLEMENTATION}

The PIF policy was issued in the form of a state Administrative Rule. An explanation of the rulewriting process will help the reader to understand the policy and its implication for all parties involved.

It should be noted that the necessity to write the policy in the form of an Administrative Rule was the first barrier the policy makers encountered.

For purposes of this study, two models have been chosen: For the analysis of the total PIF policy formulation process, the work of Charles 0 . Jones on policy analysis has been selected. For an examination of the individual segments of the policy, Lindblom and Braybrooke's model of interaction in policymaking was chosen. It is hoped that these authors' frameworks will provide additional perspective on the policy and the issues involved in making it.

\section{METHODOLOGY}

In preparation for the case study the author first familiarized herself with the subject matter. The legislation was read: the Social Security Act, Title XIX, public Law 819-97, which is known as Medicaid or Medical Assistance. The literature was reviewed for material relative to nursing home issues 
and problems. The literature was also explored for information on existing protective services for the elderly.

Following a general orientation to the subject, the focus shifted to Oregon's situation relative to use of Medicaid monies for nursing home residents, as well as an investigation of the level of care and protection the state provided for residents.

To gain perspective on what was happening in Oregon the author made weekly visits to the state capitol for meetings with the Congregate Care Consultant, who briefed the author on the structure of the Public Welfare Division, the nursing home industry, and on current issues and problems.

Research was then narrowed to the specific issue-the Personal Incidental Funds: what they were, how they were managed, for what were they spent and how they were accounted for, who protects them from whom, etc. Pertinent memoranda and minutes of past meetings were reviewed. Staff were interviewed in an effort to piece together a comprehensive view of the problems.

The author was invited to attend the Nursing Home Committee meetings at which the policy was reviewed and revised. She also attended the joint staffing meeting of the PWD and the oregon Health Care Association 
which met to review and revise the policy. An OHCA educational workshop was attended.

The author later assisted in training the state's Adult Services Supervisors in the new PIF policy, and wrote an information and procedural booklet for the PIF to be used in nursing facilities and for friends and relatives of nursing home residents. (Appendix A) The author also assisted in informing the residents' friends and relatives of the new policy, and explaining the need for their cooperation in helping manage their residents' funds. (Appendix B)

Finally, the author taught a class as part of the course for Nursing Home Administrators at Clackamas Community college. She lectured on the "Past, Present, and Future Issues of Personal Incidental Funds of Nursing Home Residents." (Appendix C)

Personal Incidental Funds policy affects a network of public organizations, private organizations, and individuals. A major organization affected, of course, is the administrator, the Public Welfare Division, and its subunits. The confederation of nursing facilities, known as the Oregon Health Care Association, is involved, as are non-affiliated individual facilities. The nursing home residents and their friends and relatives are also important parts of the network. 
An examination of the goals, activities, and communication linkages of each of these components within the PIF network gives a perspective of the network's reaction and attitudes to the policy. Following an examination of how the policy formulation process helped to create the barriers which delayed the release of policy, conclusions will be drawn as to issues that may arise from implementation of this policy and barriers which may arise to inhibit the policy's effectiveness. 


\section{CHAPTER II}

\section{FEDERAL HISTORY: MEDICAI CARE PROGRAMS}

The aged in this country have historically been considered a legitimate public assistance category. However, vestiges of the attitude that pauperism is a type of social disease have long influenced policy for old people. (Stevens 1974) As the scope of the problem expanded, social reformers asked the nation's politicians and policy writers to turn their concern toward the plight of the aged. In $1858,3.5$ percent of the population of this country were over 65 years of age. By 1928, 5 percent of the population were over 65 years. Responding to the growing problem of care for the aged, social reformers formed the American Association for old Age Security. One of the Association's basic goals was to influence public policy. To this end Jane Addams wrote her personal observations of the elderly:

There is no experience in an industrial neighborhood more poignant and heartbreaking than those connected with old age when it is surrounded by poverty and indifference and given over to neglect and loneliness. (Epstein 1928)

In the 1920's, the federal government remained passive and continued to allow local units of government 
and the states to deal with the problem of the aging. Poverty, unemployment, and ill-health were not addressed consistently and often were shamefully neglected. Medical problems were approached with an almshouse mentality. Before 1935, states had an ad hoc system of cash relief for the elderly poor. There were great differences in the types of assistance available as well as in eligibility requirements, which varied from state to state and town to town. During the early 1920's there emerged in some states a new concept for aiding the blind, the old, and dependent children as the "deserving poor." (Stevens 1974) This system was philosophically based on the old "out door" relief concept. Several states closed their almshouses, and aid for the aged became, more respectably, old Age Assistance. Twenty-eight states had Old Age Assistance programs by 1930 , leaving twenty states addressing the poverty and health problems of their aged citizens with eighteenth century concepts and methods.

The Social Work Yearbook of 1929 pointed out that the federal government was not taking responsibility for its sick and fragile elderly. 
While the dependent aged are cared for by friends and relatives in almshouses, private institutions, in nursing homes, or their own homes, or those of relatives, by private or public relief, the most conspicuous means by which the aged receive care is by private institutions. (Brody 1974)

By 1930 the economic depression made it impossible for private institutions to bear the financial burden and responsibility for the ill and fragile elderly. In 1933, 25 million Americans were dependent on public welfare aid (Brody 1974), and there was strong support for federal legislation to relieve the overburdened private institutions and state-financed programs.

The 1935 Social Security Act approached the problems of aging, poverty, and ill-health with a two-pronged social philosophy. The first tenet was a social insurance approach, as reflected in Title II of the Act. This section is often described as a forerunner of the era of "enlightened capitalism." The second part of the philosophy was a commitment to the states' rights in provision of public assistance. Title I of the Act reinforced state assistance programs, calling for the federal government to contribute 60 percent of the money the state would give its elderly citizens, up to $\$ 50$ per month. (Stevens 1974) This contribution was a great relief 
for the states involved in public assistance. There was one drawback for ill elderly in that the writers of the Social Security Act were men sensitive to the almshouse approach who to some extent confused the private nursing facility with the old public almshouses. Therefore elderly poor Americans, 25,000 of whom resided in nursing homes, were ineligible for old Age Assistance under Title I. (Brody 1924) Not until 1939 were Old Age Assistance payments made available to residents of nursing homes.

A general debate continued in this country over how to meet the needs of poor people, while a specific debate ensued over how to meet the needs of the vulnerable elderly. By 1940 those who wanted general health and medical benefits for all Americans were losing the debate to those who wanted health and medical benefits only for those categorically needy. The elderly were being given top priority based on the fact that persons over 65 must try to meet health expenses that are three times the rate for younger persons. At the same time older patients have half the income of the younger persons. (Meyer 1970) The debate prompted amendments to the Social security Act.

The Social Security Amendments of 1950 expanded 
health services to the poor elderly. By including federal cost-sharing for hospitals, and medical care to those participating in the federal public assistance grants in aid program, the federal government launched itself into the business of providing medical care for the poor. The system the federal government used was called "vendor payment," in which the federal government shared the cost with the state. The state then paid the vendor (provider of care). Two million older Americans qualified for assistance under this complex system of vendor payments.

Early in 1960 there were still ten states that had not entered into the vendor system to provide medical care for their elderly public assistance residents .

The Kerr-Mills laws, as the 1960 amendments to the Social Security Act were known, established two provisions under public assistance programs for citizens over 65 . The first was an increase in the amount the federal government matched the states for medical vendor payments. The second provision established a new public assistance program to be known as Medical Assistance for the Aged (MAA). (Stevens 1974) Inherent disadvantages to both recipients and providers of services soon appeared. 
The elderly resented the stigma of their public assistance status. The providers did not approve of the below-cost fee schedules they could charge for their services, and the states felt the administrator's burden of a double-payment arrangement with the federal government.

The struggle for viable alternatives continued until the advent of Title XVIII, Medicare, of the Social Security Act, which created a national policy based on entitlement and brought the first systematic plan for compulsory health insurance and supplementary medical insurance for citizens 65 and over. With this legislation also came Title XIX which had potential for providing medical services to the "medically indigent" in all welfare categories. (Stevens 1974) For the elderly, this program would pay for out-ofhospital care and nursing home care. Unlike Medicare, Title XIX was not based on entitlement and medical insurance principles, but rather on eligibility. Medicaid was an extension of all other medical assistance legislation for the elderly that was considered welfare. In fact, the Title XIX, Medicaid or Medical Assistance program, was administered by the Public Welfare Departments in each state. According to the provisions of Title XIX, each state was to create a plan to cover the entire state, 
provide for state money to cover the state's financial share of 40 percent, establish a fair hearing process, administer the funds efficiently, and establish other regulations and safeguards. Each state had the choice of entering into this plan for medical assistance for its residents. By January 1977 only one state, Arizona, did not participate in the Medicaid program.

The initial Medicaid legislation (US Statutes at Large, Vol. 79, 1968) required every state to establish a plan to provide "skilled nursing home services." This new legislation pointed to the lack of any uniform national or even statewide definition of services in the nursing home industry. The social Security Administration began, with the Department of Health, Education and Welfare (HEW) to develop early regulations for the newly instituted service of extended health facilities.

One weakness of the program that was to cripple the implementation of Title XIX was the failure to give HEW the authority to administer the program before the states began to act. As a result, the states had already begun to interpret the law before the specified federal regulatory agency was established. This agency was the Medical Service Administration 
of the Social and Rehabilitation Services of HEW. (Stevens 1974) The fledgling agency worked at a disadvantage for many years as a result of this oversight in the original legislation. The MSA staff remained small and was often weakened by interdepartmental competition which severely hampered their authority; the program began without a clear mandate and no relevant regulations for the states have resulted.

A glance at the history of federal regulations provides some insight into the problems the states faced in handling the Personal Incidental Funds allotted each elderly person in the program. In the case of the Title XIX legislation, regulations to guide management of this money did not appear until one year after the law was passed. The Handbook of Public Assistance, "Supplement D," was issued June 1966 (Stevens 1974). By this time, both California and New York had established precedents to the law; it was not until 1969 that the basic regulations for administering the programs were issued. The Medical Services Administration was barely able to meet the deadline of 1970 for establishing general federal standards for nursing home administrators and writing an official definition for skilled nursing homes. 
The regulations were finally issued for Intermediate

Care Facilities in October 1971. (Stevens 1974)

Following the issuance of regulations, definitions

of procedures evolved. In clarifying the procedures

the Personal Incidental Funds were given the most

cursory attention.

The regulations concerning PIF for skilled

Nursing Facilities, which evolved under section 405.1121,

item 6 , read:

[patient] "...may manage his personal financial

affairs, or is given at least a quarterly

accounting of financial transactions made on

his behalf should facility accept his written

delegation of this responsibility to the fac-

ility for any period of time in conformance

with state law..." (45 CFR)

By March 29, 1976, the PIF regulations for

Intermediate Care Facilities had evolved a slightly

more protective regulation (45 CFR 249.12):

[patient] "...may manage his personal financial

affairs, and to the extent under written

authorization by the resident, that the

facility assists in such management, that

it is carried out in accordance with para-

graph (a) (l) (iii) of this section."

Paragraph (a) (1) (iii) reads:

"A written account, available to residents and

their families is maintained on a current basis

for each resident with written receipts for

all personal possessions and funds received by

or deposited with the facility and for all

disbursements made to or on behalf of the

resident." (45 CFR 201.0) 
The lack of federal regulations in the early stages of the PIF program left a void. That void has been filled with misunderstanding and sometimes irresponsible interpretations by federal and state governments, the nursing home industry, and families of the residents.

The failure of social rehabilitation services to issue explicit and uniform regulations and procedures was publicly revealed in November 1975, at a meeting of the sub-committee on long-term care, part of the U.S. Senate Special Committee on Aging, in a paper entitled "Controls over Personal Funds of Medicaid Patients in Nursing Homes."

The testimony was given by Gregory J. Ahart, Director of the Manpower and Welfare Division of HEW. His testimony concerned existing federal and state regulation of PIF management. The federal regulations "required that patients be allowed to manage their personal financial affairs, or be given at least a quarterly accounting of financial transactions made on their behalf." These were for skilled nursing facilities while intermediate care facilities required a "written account be maintained and be available to residents and their families." He cited the notable lack of HEW interpretive instructions dealing with: 
1. Safeguarding and accounting for patient funds,

2. Determining what services or items provided by the institution could be properly charged to patients' personal accounts, and

3. What disposition was to be made of personal funds upon patients' deaths or discharges.

Included in the study were HEW interpretive instructions that had been sent to individual states in answer to particular questions. These surveys and the responses varied from state to state. As a result, the states' regulations reflected a fragmented and incomplete approach to protecting patients' funds.

The resulting national problems were:

1. The facility policies and procedures for adequately accounting for patients' monies were either weak or non-existent. Poor accounting techniques were employed, such as lack of receipts for credits to the patients, lack of quarterly accounting, mixing of general funds with patient funds.

2. There were discrepancies between patient ledger balances and bank accounts resulting in shortages for patients.

3. Patients were inappropriately charged for medical supplies and services. 
4. Funds of deceased and transferred patients were retained by facilities.

5. Interest earned on patient funds was retained by facilities; other irregularities involving interest exist.

6. Patient funds were used to pay operating expenses of care facilities.

Although each state has its own historical perspective on assisting its dependent aged, each also reflects the federal government's involvement in its public welfare programs after the Social Security Act of 1935 was instituted. Oregon's history is no exception. 


\section{HISTORY OF TITLE XIX IN OREGON}

With the advent of the historic social security legislation of 1935 oregon, among other states, began to receive federal financial funding for its older residents. These benefits were to be provided to those elderly who were eligible: the poor elderly and the physically and mentally disabled constituted the target population. The elderly nursing home resident fell squarely within the scope of the new legislation. Under this Social Security legislation elderly nursing home residents in the state of oregon received their old Age Assistance benefits directly and then paid the nursing homes for their services. Included in the old Age Assistance payments were small amounts of money that the patients were to use as their own personal funds. The amount of this personal spending money was established by the state.

By 1956 the state of Oregon provided a broad range of medical services for recipients of federal old Age Assistance payments. A process of allocating funds was used based on a formula set up by the federal government. Payments to receipients were limited 
only by the availability of appropriated state funds. Funds appropriated from state tax monies were to provide "minimum adequate medical services." At this time the state used a very complex system of payments which distinguished between medical and non-medical costs. A partial vendor payment was sent to the nursing home for cost of care and a partial payment was sent to the patient. The patient paid the nursing home out of his allotment a specified amount for any non-medical services and retained a specified sum for his own personal needs. There were no written regulations or procedures for protecting the personal monies, which were received by the patients from the state on a monthly basis.

The complex partial vendor payment system was used until mid-1959, at which time oregon converted to a vendor payment system. This system called for direct billing from nursing facilities to the Public Welfare Department. The Public Welfare Department sent the client a clothing and personal allowance ranging from three to seven dollars per month. The amount of the payment was determined by a "needs formula" set up by the state. At this time only informal agreements existed between the nursing home administrators and state officials for protection 
and management of patients' personal funds.

The Medicaid program created under Title XIX provided coverage for persons designated as needy, including the aged. The Public Welfare Division (PWD), operating under the guidance of the Governor's office, assumed responsibility for the administration of the new law, through its thirty-six Public Welfare Departments. The medical assistance payments available to needy persons were equal in amount, duration, and scope for all eligible persons. The federal legislation required that the client's income be applied first to meet maintenance needs and then medical needs. In Oregon it was estimated that 70 percent of nursing home patients eligible for Title XIX funding had some private income (e.g., pension, income property, Social Security, etc.). The state established fifteen dollars a month as the amount of money that the patient would receive in personal funds. In the 1960's there remained a vacuum in state policy, as no guidelines were established to protect the patient's fifteen dollars as it was dispersed or accumulated. (Arbuckle 1976)

In 1969 Oregon developed formal contacts with skilled nursing home facilities participating in the Title XIX program. In these contracts can be found 
traces of what has developed into a public policy to protect the personal funds of nursing home patients. Part I, Item $U$ of the original contract calls for agreement by the skilled nursing home:

To maintain an accounting as prescribed by the Public Welfare Division of each recipient's personal funds managed by skilled nursing home, to permit an audit by the Public Welfare Division of such accounting, and within 10 days following the death of a welfare recipient to forward the recipient's personal funds to the Public Welfare Division, Estate Administration unit, ...

That any breach or violation of any one of the above provisions shall make this entire Agreement, at the Public Welfare Division's option, subject to immediate cancellation.

In 1971 the Administrator of the Public Welfare Division asked the Attorney General of Oregon for an opinion of the amount of influence the PWD had over the nursing homes to require their acceptance of responsibility for management of a welfare recipient's clothing and personal incidental fund allowance. The Assistant Attorney General and Counsel to Public Welfare Division responded to the inquiry:

The State agency has authority to provide for agreements with every person or institution providing services under the State plan under which such person or institution agrees to keep such records as are necessary to fully disclose the extent of the services provided to individuals receiving assistance under the State plan. 42 USC $\$ 1396$ (a) (19). 
In situations where the person or institution takes the responsibility to hold and disburse a welfare recipient's clothing and personal incidental funds, the state agency may require an accounting, prescribe the form and contents of the accounting and audit it.

This requirement can be justified upon the grounds that the agency must determine that the recipient's personal allowance is not being used to pay for care or services for which the agency is billed by the nursing home.

In situations where the person or institution takes the responsibility to hold and disburse a welfare recipient's clothing and personal incidental funds, the state agency may require an accounting, prescribe the form and contents of the accounting and audit it. [Emphasis supplied.] (Nov. 2, 1971, Juras from Kathry v. Kebty.)

The state used this authorization in only a limited manner and injected two restraints upon the management of PIF. One concerned the return of the client's personal incidental funds to the Public Welfare Division within 10 days after the client's death. The other asked for some form of auditing. These requirements became part of the contract for services which the skilled nursing facility signed with the state. This limited protection did not yet apply to other types of facilities.

As the principles of the Title XIX legislation were implemented, piecemeal, by the state, it became obvious that more detailed procedures and regulations 
were needed in order for the original spirit of the law to be put into operation with uniformity and consistency. In mid-1974 the amount of personal incidental fund monies allocated to each recipient was raised to twenty-five dollars per month. This amount was established with the advent of the supplemental Security Income (SSI). As the amount of personal funds increased, the problems of managing and protecting those funds also increased. At approximately the same time, the Medical Assistance unit of the Public Welfare Division was directed by the state to include in their area of responsibility the supervision of personal incidental funds. The already-established "medical Independent Review Team" was given direct responsibility for the PIF.

In the Spring of 1975 the federal government conducted an audit of Oregon's Medicaid program. Upon completion of the audit the federal team notified the state that they felt Oregon was not adequately monitoring the personal incidental funds of nursing home patients. As a result, the Public Welfare Division developed an accounting form that was to be used by the nursing home for each Title XIX patient whose PIF the home was managing. Conflict developed over the form's acceptability to the facility 
administrators. To avoid the new accounting form, some homes simply declined to accept responsibility for managing patients' funds. In cases where patients had no friends or relatives to take on this responsibility, the Public Welfare Division tried to insist that the home carry out its responsibility. However, at this time, the federal policy was so vague that each case was confronted individually.

The refusal to respond to accounting procedures was not the only difficulty encountered by the state in dealing with nursing home facilities. An "all inclusive rate" had been established by the contract between the state and the facilities, to determine what items were to be charged against patients' PIF. The facilities, for their part, wanted to know whether the state, the facility, or the clients were prepared to assume the cost of increased bookkeeping needed to upgrade the PIF accounting. In addition, nursing home staffs were reporting that relatives and friends responsible for managing PIF funds were misusing them. The policy at this point was not detailed enough to answer the questions and solve the problems concisely or consistently.

The first official response to these problems was Rule Five of the Handbook, revised in November 
of 1975. Rules and regulations for skilled nursing facilities were set out in The Guide Book for Skilled Nursing Home Services: Public Welfare Medical Assistance Programs. The specific revision of Rule 5, tried to established a definition of the kinds of items or services chargeable against PIF as well as definitions of "restricted" items. It also modified procedures for record-keeping. For the first time the issue of how and where the facilities kept the monies they managed emerged. Rules 5 specifically stated that if funds were kept in a bank, they were to be separate and apart from the facilities' accounts, and that any interest earned on PIF was to be credited to the patients' accounts. By January 1976 regulations covering Personal Incidental Funds were extended to include intermediate care facilities. Regulations that could be found in the adult service workers' manuals, medical assistance manuals, and facility guides proved once again to be inadequate for the task of properly protecting the residents' funds. Adult service workers were asking policy quesions of their branch supervisors; the supervisors in turn consulted their branch managers; and the branch managers sent the queries to the desks in salem, where they were dealt with individually in the Adult Services 
Unit or the Medical Assistance Unit. At one time or another, each of the following problems was raised:

1. How to demand reimbursements from nursing homes for charges inappropriately billed to PIF accounts?

2. What to do when nursing homes that manage patients' PIF monies refuse to purchase anything for patients.

3. If a home is misusing or abusing patients' PIF, when will the state's payment for services be withheld, and will it be withheld only for the specific client involved or for all medicaid clients in that facility at that time?

4. At what level of enforcement is the PWD prepared to withhold payment because of PIF abuse? That is, will be patients be moved from the offending facility?

5. Could fines be used (1974 legislation) to stop abuse?

6. What are the legal procedures for instigating investigation of suspected fraud?

Since two units (Medical Assistance and Adult Services) were writing policy on the same subject, a communication lag was created between the state and the workers at the branch level. For example, the 
the branches also had to cope with the fact that there were two inspection and monitoring teams--one under the PWD, the Medical Independent Review Team, and the survey team from the Health Division. Rule Seven, item 8 , of the Pharmaceutical Guide stated that buying "Kleenex" is the responsibility of the client, while Rule 5 of the Intermediate Care Facility Guide and Skilled Nursing Home Guide lists "tissue" as an item to be furnished to patients.

The state faced the problem of how far it could allow a facility to hedge on proper charges and management of patients' PIF accounts. The state's philosophy was that the public welfare agency had recourse to civil action to recover funds from a nursing home on behalf of the state, and that the clients had recourse to Legal Aid. Feeling among bureaucrats at the state level, however, was that fraud on the part of the facility would be almost impossible to prove. The state of oregon had never tested this theory in the courts.

As this policy was being revised an adult service worker, who saw herself as an advocate for her nursing home clients, introduced disgruntled 
patients to an attorney who brought the case before the courts. As a result of the lawsuit fifty patients won $\$ 500,000$ punitive damages and their PIF monies. This case of abuse of funds had been known to the state agencies involved, which had chosen not to act because of the belief that there was insufficient documentation. The state's hesitancy to challenge the facilities and thus create conflict was a doubleedged sword. If the state takes an inflexible stance on compliance, relations with the industry become unfriendly and uncooperative. This strains the working relationship between the Public Welfare Departments and the nursing home industry. However, if strict compliance is not required the resident may suffer from inconsistent quality in care and services and the agency's credibility will be in doubt.

In the past, a root cause of the state's hesitation to pursue an issue lay in the wording of the federal law. Much of the Title XIX wording is vague and ambiguous; a request for an interpretation from the Department of Health, Education and Welfare could often result in monts of delay.

Although the PWD had been cautiously developing rules and regulations for implementing a new policy, 
major problems developed in 1975 and 1976 that clearly indicated noncompliance and misunderstandings between care providers and the PWD. A major attempt was made to begin untangling the knot of conflicting interpretations of PIF policy that was blocking proper management of the residents' funds. A special pilot project was instituted in 1976 which culminated in a report entitled "Personal Incidental Fund Account Audit."

This project was developed by an adult service worker under the auspices of the Adult Services Unit of Multnomah County East Branch, Public Welfare Department, and the unit's supervisor. In the report, PIF-allied trouble spots were identified. One of the many issues which emerged was ignorance of PIF policy and procedures on the part of service providers and adult service workers. It was noted that facilities' staff people displayed a surprising lack of information on PIF. Not only was knowledge and "top of the head" information missing but the written source books were not accessible to the staff. Many facilities did not have the Guides available and it was not uncommon to find one section of the Guide kept in one area of the facility and a different section in another area of the facility. 
The "hottest" issues were charges for pharmaceuticals. Over-the-counter pharmaceuticals (i.e., household remedies, medicine chest items) were to be charged to the "all-inclusive rate." Also creating difficulty were such practices as bulk buying vs. unit doses, computerized billing (with kickbacks to the pharmacies on over-the-counter pharmaceuticals), the possible return of drugs to pharmacies with consequent credit to the facility rather than the residents or residents' PIF. Another issue was brought out in the 1976 Pilot Project involving subtle issues of patients' well-being and personal priaje. Problems evolved, for instance, in determining maintenance grooming vs. elective care. Patients would often use PIF money for personal grooming aids, rather than feel ridiculous with the facility's definition of proper care.

Another issue the report discussed was the lack of information at the disposal of family and friends concerning the Medicaid payment. Families had no information about what they should pay to the facility from the PIF, nor did they have information about suggestions for creative uses for PIF funds. The report suggested that the role of the adult service worker be expanded to that of interpreter of the regulations and procedures in order to help the family and friends identify residents' needs or potential needs. 
The report further stated that, as of April, 1976, and in spite of state and federal requirements, there was still little or no control or protection of the funds. "State and Federal regulations require control, but so far delegation and followup has not been required." (Hawes 1976 )

The report listed 25 recommendations to the state for better protection of the funds. As a result of this input the Public Welfare Division was in possession of even more information when it began its task of drafting a new policy to protect the nursing home residents' personal incidental funds.

In summary, Oregon first received federal funds to help care for its needy elderly in 1935 as a result of the original Social Security legislation. Today, under that same legislation, Title XIX provides that all Medicaid recipients who reside in nursing facilities must receive at least $\$ 17.20$ per month for their personal needs. The responsibility for the protection, management, and proper spending of these monies is the responsibility of the state Public Welfare Division. The next chapter will describe how that agency set out to accomplish the task. 


\section{CHAPTER IV}

THE PERSONAL INCIDENTAL FUND POLICY:

\section{A CASE HISTORY}

It was apparent at the outset that a new policy was needed to clarify the use and management of residents' Personal Incidental Funds. This chapter will describe the development of that policy in oregon.

In the summer of 1976 the Manager of Adult Services, Public Welfare Division, of the state of oregon assigned to the Congregate care consultant the task of drafting a new policy concerning the Personal Incidental Fund (PIF) Prior to drafting the policy, the Congregate Care Consultant reviewed all the correspondence, memoranda, and minutes of previous Division meetings regarding the Personal Incidental Fund policy. By fall of 1976 a draft of the proposed policy had been prepared.

In November of that year a committee, known as the Nursing Home Committee, was formed to facilitate communication between the Public Welfare Department offices in Salem and the PWD field workers. The comittee was to address itself to issues of nursing home care in general with, in the beginning, an emphasis on the PIF. The Congregate care consultant 
for Adult Services was appointed chairperson of the comnittee. The first agenda item was the PIF policy. The committee members were appointed by the Consultant with a view to obtaining the widest possible range of input. The members included: the supervisor of Medical Programs of the Medical Unit, Public Welfare Division; a supervisor from Adult Services, West Branch, Portland Public Welfare Division and three Adult Service Workers representing various demographic areas in the state (one from the Corvallis Branch office of the PWD, another from the East Branch office in Portland, and a third from the predominantly rural Florence Branch). The sixt member of the Nursing Home Committee was a social worker on the Medical Independent Professional Review Team, Unit III.

In addition to the chairperson and the six members, resource people representing other sections and divisions of the Public Welfare Division were asked to serve on the committee.

Before the PIF policy proposal was disseminated to the committee, it had to be reviewed by the staffs of Adult Services, Medical Assistance, and Field Operations sections of the Public Welfare Division. Attached (Appendix D) is a copy of the proposed policy which was reviewed by these staffs. 
On November 12, 1976 the Chairperson advised the members of the Nursing Home Committee of the goals and objectives of the group. Since the committee's first priority would be reviewing the proposed PIF policy, a copy of the material was forwarded to each committee member.

The First Nursing Home Committee Meeting

On November 24,1976 the Nursing Home Committee met in Salem and lasted a full day, from 9:00 a.m. to 4:00 p.m. All members of the committee attended. Since this was the first time the committee members had met as a group, introductions were performed and an agenda set for the following meetings. The Chairperson then asked each member to list, in order of importance, the barriers they saw to efficient and effective service delivery in nursing homes. Then, by consensus, the lists were combined to form a master roster of problems, which were then discussed, with the most urgent considered first.

Communication and coordination were listed together as the first barrier to effective service delivery in nursing homes. The committee felt that a more responsive and timely communication system was needed to replace the one currently used by agencies within the state's 
Department of Human Resources. It was also thought that coordination of the agencies would be enhanced by improving the communication system. Before such effective coordination could be achieved, committee members felt, there was need for agencies within the Department to be more open to each other's requirements, abilities, and limits.

The second barrier to good service delivery in nursing homes was the lack of properly trained nursing home personnel. The committee agreed that short and perfunctory training programs left personnel with few skills. Members noted that turnover in staff was frequent, often as high as three times in a year for one position.

Inadequate staffing of local branches of the Public Welfare Division was considered by Committee members to be the third most important problem. The average caseload of 175 clients per adult service worker can climb to over 200. The committee expressed the view that this issue would have to be addressed in the near future if the social services which the Public Welfare Department has to offer were to be at all effective. The existence of too many and sometimes conflicting regulations governing the various agencies was fourth on the committee's list. Regulations are written by 
myriad state and federal agencies including Adult Services, Medical Assistance, the Health Division, the federal Social Security Administration and HEW agencies, the Office of Long Term Care standards, and the Social Rehabilitation service. The reading, assimilation and interpreting of these regulations, committee members said, requires a disproportionate amount of the workers' time. In addition, confusion can sometimes result from conflicting interpretations of the various regulations. The committee had difficulty finding concrete terms to describe the fifth barrier to effective service. All agreed that the issue of patients' involvement and control in their lives as nursing home residents is a complex and subtle one. An important aspect of the issue involves patients' rights, in light of the varying capacities of the residents, to help plan their lives in institutions. This delicate philosophical question is aggravated by the amount of time it requires of adult service workers to negotiate with aged, often confused and querulous clientele. The members of the Nursing Home Committee concurred overwhelmingly with the philosophical position that all clients should be encouraged to maintain the maximum possible autonomy and self-responsibility consonant with their physical and mental conditions. 
The adult service workers on the committee agreed agreed that the sixth barrier existing to their efficient and effective service was also the easiest to correct: their complaint focused on the physical absence of the written regulations which are mailed to their Branch Offices. Often these written regulations, along with interpretations of regulations and office memoranda, are not accessible to them. The workers are sometimes embarrassed to find that a client, a client's friend, or a nursing home administrator wants to discuss a new regulation of which the worker has no knowledge. The worker may not see the new material for a week after the inquiry. There are various reasons for this delinquency--late mailing from the state capitol, inefficient posting, incorrect routing through the Branch, even getting stuck in someone's in-basket or carried off in their brief case--but whatever the reasons, the result, they felt, was inadequacy of service delivery to their clients.

After an in-depth discussion of each barrier as outlined above, the committee continued the discussion until noon.

After the noon recess the meeting was reconvened by the Chairperson who stated that the next item on the 
agenda was the proposed Personal Incidental Fund policy. After refreshing their memories by referring to the copy of the proposed policy received prior to the meeting, a discussion ensued from which several important issues emerged.

The first issue to be adaressed was that of locating direct responsibility for administering and monitoring the PIF. The members felt confused about the degree of responsibility of the Health Division, adult service workers, or the Medical Independent Professional Review Team held for the policy. (The Medical Independent Review Team (M/IRT) is an arm of the Medical Assistance Unit of the Public Welfare Department and some responsibility for the PIF was mandated to them by Title XIX of the federal regulations. The social worker on the Team audits fund accounts and examines types of expenditures as part of the yearly facility review process.) The committee described the Health Division as the "inspection team" for the Health Facilities Licensing Certification section of the state. It is responsible for the certification of facilities but workers are not required to ascertain if patients' funds are properly protected and managed.

It was agreed that the Adult Service Worker is the person closest to the patient and most familiar with their personal funds problems. The adult service 
worker has the data listing who is handling the funds for the patient, what the funds are spent for, and sometimes knows the balance in the patient's account. But the committee noted that actual involvement varies considerably from worker to worker and branch to branch. One worker from a small town stated that she had dollar to dollar accounting of her residents' PIF and was constantly in communication with nursing home administrators and relatives of residents concerning expenditures. The worker from the urban setting, however, who had a caseload of approximately 190 nursing home residents, stated that she could not give each resident's PIF accounts such individual scrutiny. The privilege of developing a relationship with the client's family or nursing facility administrator, she said, was not feasible with such a large caseload. A worker in this situation is not able to be constantly alert to abuses or mismanagement of the residents' funds.

The committee felt that the newly drafted material did not address the issue of administrative responsibility for the funds. They asked that the new policy create procedures for dealing with everyday problems such as the proper way to file a complaint if abuse was discovered. They wanted stated explicitly the person responsible for making a proper audit of the accounts. 
They want to know when audits should occur and whether administrators responsible for the proper protection and management of the funds would be available to the Branches as resource persons when interpretations were needed.

The next issue the committee members addressed was that of providing implementors of the new policy with adequate incentives. It was acknowledged that everyone concerned with the nursing home residents hopes to be able to provide the residents with good care and services. However, those who are providing those services are already heavily burdened with work. The committee wondered why the new policy did not deal with incentives for the service providers who would be greatly affected.

Two examples of the need for incentives were cited during the discussion. First members of the committee discussed the adult service worker who, under the proposed policy, would be asked to help find friends and relatives (or if there are none, the often-unwilling facility manager) to manage the funds of residents who ask for help. After finding such a delegate, the worker would then have to explain the system. The newly drafted material also requires the adult service worker to monitor the Public Welfare Division's 713 PIF 
Accounting Forms. The delegate must, under the new policy, contact the worker when an expenditure of more than $\$ 25$ is contemplated. Some members of the committee were concerned that the time needed to implement these new procedures should not simply be added to the worker's already heavy case load. It was also questioned whether, if additional work time is not given as an incentive, the workers might not feel too overwhelmed by the additional work to effectively administer the policy.

A second example of a situation in which lack of incentive might render the policy less effective was the case of the nursing home administrator. Since a nursing home facility is a profit-making institution, and the new policy will require additional staff time, the committee wondered if the incentive most appropriate in this case would not be reimbursement for the staff time which would be required to properly manage and account for patients' PIF.

According to the proposed policy, if a facility accepted responsibility for residents' PIF, it would have to keep an accurate account using the PWD 713 form, in triplicate, every three months; give a copy of the PWD 713 to the client and the client's adult service worker; keep the money accessible to the 
resident, and open a bank account when the balance of the PIF exceeded $\$ 75$.

An issue which created general uneasiness among the committee members was that of patients' incapacity to manage their own funds. In the proposed policy the physician could assess the resident who appears to be physically or mentally incapable of managing the PIF monies and decide whether a relative, friend, or nursing home administrator was needed to help manage the money. Members questioned whether physicians would be willing to spend enough time with the patient to make accurate assessments. The committee noted that this was not applicable for the cases when guardianships, conservators, or representative payees had already been established. Members of the committee felt that a procedure was needed to protect the resident who is not able to manage the PIF funds but who is unaware that the funds are not being spent properly. These individuals are often lacking things which could be purchased to enrich their environment and bring them some stimulation.

The last issue to be discussed regarding the proposed PIF policy pertained to the expenditure of the PIF monies. The committee thought a definition of appropriate expenditures was needed. The incessant problem of what the facilities can ask the residents 
to pay for and what the facility should consider paid by the state as part of the "all inclusive" payment agreement was mentioned. The committee agreed that it would be hazardous to come up with a list that might appear to be a model shopping list, and it was decided that a "suggested" list would be appropriate.

After committee members discussed the issues of administrative accountability, motivating the implementators, and facilitating appropriate spending for residents' enhanced well being, it was decided that members would each submit their revisions.

The Chairperson explained to the committee that the issue of administrative accountability for the proper management of the funds was one which the Medical Assistance unit of the Public Welfare Division was investigating at that time. She hoped that part of the policy would soon be available for the committee's review.

The problem of providing those workers who will be implementing the policy with adequate incentives was difficult for the Chairperson to respond to, since it appeared that there was no way of lessening the adult service workers' caseloads or paying nursing homes for their costs. The incentives would have to lie in the clarification and facilitation the policy provided those 
who worked closely with the residents' PIF. In the nursing home facility's case, complaints from residents or residents' families should be greatly reduced and the time gained could be considered an incentive. All in all, the Chairperson pointed out, the basic incentive would have to be the benefits the residents will receive from having properly managed, spent, and accounted for personal funds.

The issues of patients' incapacity to manage their own PIF and appropriate means to suggest expenditures were tabled until the next meeting at which time, the Chairperson said, she would have new policy materials addressing these issues.

The committee's final task for the day was to submit their revisions. A discussion of specific revisions to the original proposal follows.

The first major revision involved the proposed policy's lower limit of $\$ 25$ for expenditures by delegated managers. According to the policy, expenditures of $\$ 25$ and over would required approval by the patient's adult service worker. The committee felt that $\$ 25$ was too low and should be revised upward to $\$ 50$. Members felt that adult service workers' time would be conserved if the amount was higher. The revision was accepted. Another specific revision the committee asked for 
was a clarification of the statement in the proposed policy, "to deposit accumulated PIF of $\$ 75$ or more in interest-bearing accounts..." The committee wanted it clear that the monies are to be deposited in an interest-bearing account when the accumulated PIF reached $\$ 75$. This revision was also accepted.

Another suggested revision was to re-word the section of PWD 452, signed by delegated managers, to read, "I will deposit the money in trust." Deleted was, "I will deposit the money in a joint interest bearing account." The revision was made to satisfy committee members who thought this money should not be construed as a joint account held by the delegate and resident. It was thought the new wording might eliminate any confusion in the minds of the delegates as to whose money they were managing. Again, the revision was accepted.

Subsequent to adoption of the revisions, committee members turned to a discussion of two major areas of concern. First of all, precisely what medical services or supplies should be paid for by the PIF monies? Two committee members offered to research the question and report their findings at the next meeting.

The second area of concern was how the Nursing Home Committee could simplify the facilities' responsibility for depositing all residents' monies in interest 
bearing accounts. One member stated he had read of a system in New York state and would research its applicability to conditions in Oregon.

The new Nursing Home Committee had spent a very full day discussing the general problem areas in service delivery to nursing home residents, the issues which emerged from perusal of the proposed PIF policy, and in making specific revisions to the proposed policy. The meeting ended with members accepting assignments pertinent to specific policy issues at the next meeting. Thus at the end of their first meeting, the committee members had made an energetic start on their commitment to discuss, review, probe, and revise the proposed policy for the protection of nursing home residents.

The Second Nursing Home Committee Meeting

The second meeting of the Nursing Home Committee was held on December 9, 1976. The Chairperson opened the meeting by displaying a morning paper with the story of a lawsuit in which it had been alleged that the Personal Incidental Fund monies of thirty-two nursing home residents in Multnomah County had been misused. The jury found the facility's owner and administrator guilty of misusing $\$ 17,000$. The court had levied a fine of $\$ 500,000$ in punitive damages to be divided among the residents or their survivors 
in addition to restitution of their PIF monies.

The committee discussed the issues involved in the case, noting common problems they had observed in other situations. Comingling of patients' monies with facilities' funds was an issue in the court case and one with which members were familiar from their field experience. The defendants in the court case had put the patients' monies into the same bank account as the facilities' operating funds, in effect using the patients' money for their own expenses.

The discussion of the court case reflected the diversity of the committee members' backgrounds. Some members had years of experience in the system and although they were dismayed to hear of the abuse they were certainly not as shocked as the committee member with fewer years' service in the nursing facilities arena. The rural and small town adult service workers were surprised that the adult service worker for the residents who became involved in litigation had not been in sufficiently close contact with the patients to prevent such abuse of their funds. According to one small town worker, rural nursing home administrators often use the adult service worker as an advisor on patient needs.

Workers from rural areas also pointed out the 
importance, in their experience, of good public relations. An administrator in a small town needs to maintain a good public image; being in constant contact with neighbors means the reputation of his facility reflects upon the administrator's personal repute. Workers from the Portland area agreed that often the anonymity of the facilities' owners and administrators shields them from community censure. Often, they said, facilities are owned by corporations, and ownership is often not public knowledge.

As the committee continued to discuss the court case, the diversity of experience between line staff, who have direct service contacts with residents, and those who act as administrative staff became apparent. The line staff felt that perhaps quick action by the state could have prevented the guilty parties from misusing the funds, or that the state could have, at the very least, demanded an immediate return of the PIF monies. The administrative staff seemed to have a greater understanding of the time-consuming checks and balances in the system. They said the system can only protect the rights of the residents through the means it has available. The process gives little legal authority to the Adult Service Unit or Medical Unit which can only ask the facility to desist from abusive action. 
If the facility does not change its practices, it is up to field workers and the administrative staffs to bring documentary evidence to the Attorney General's attention and seek relief through the courts.

The "Catch 22" for field workers was collecting documentary evidence. They felt they had little enough time to spend with their clients without trying to document alleged fraud. However, the administrative staff insisted this process had to be maintained to preserve the integrity of the system.

The discussion of the court case and all its implications ensued for over an hour. In this way the committee identified many of its different view points, frames of reference, and experiences. The discussion also highlighted the need for a clear and enforceable policy which would protect the residents from similar occurrences in the future.

The committee member who had agreed to research banking procedures for nursing facilities which manage their residents' PIF reported that the facilities would be depositing the patients' individual funds when $\$ 75$ had been accumulated. This member stressed that implementation of this new procedure would have to be simple and relatively easy, and it was agreed by the committee that a greater probability of compliance by 
the facilities would occur if the procedure was streamlined and expedient. The committee member reported that he had contacted several major banks and savings and loan associations in oregon concerning their willingness to help facilities set up the required accounts. Without exception those financial institutions contacted expressed willingness and some enthusiasm about assisting the facilities.

The Chairperson stated that she would continue to work on this new banking system. She said she would suggest the system to the Oregon Health Care Association, the nursing facilities' association in this state, as soon as it had been reviewed by other administrative staff members.

The afternoon session of the Nursing Home Committee's second meeting began with a report on medical expenditures from PIF funds. The committee members stated that they had discussed a sequence of actions for the client, or the client's delegate, the facility, and the adult service worker to use when medical expenditures were needed. They emphasized the first question that must always be asked before paying the facility for medical services or supplies is: should this have been covered by the "all inclusive rate"? If the answer is in the negative, they suggested that the facility call the 
worker and explain the need. The adult service worker would then try to find medical needs monies, and, if there were none, investigate the availability of miscellaneous needs money within the agency. Only if all these attempts to meet the residents' needs prove futile should the Personal Incidental Funds be used. The Commitee agreed that the sequence of actions appeared to be logical and would help protect the residents from having to use their personal funds for medical purposes.

The committee then turned to reviewing the proposed Personal Incidental Fund policy. They all agreed that the policy as revised at the last meeting would facilitate better management, protection, and accounting of the monies. The specific revisions that had been made clarified the issues of when monies shall be deposited in interest bearing accounts and how the account is to be established, and when the adult service worker shall be consulted concerning an expenditure.

The issue of protecting the resident who is unable to manage personal funds but is unaware of the possibility of delegating the management of the PIF was again explained by the Chairperson. She displayed a form she had developed from a model by the social security Administration for use by physicians at the time they felt their patients were incapable of managing 
their funds. The committee felt more positive about this part of the policy at this point than they had at the first meeting.

Following the review of the revised policy, the committee began planning for its implementation. It was unanimously agreed that the first presentation of the policy to the residents, residents' friends or relatives, and nursing home administrators was the crucial step, and that this step could only be taken after careful planning. The residents would be told about the change of policy by their adult service worker during their regular visits. If the residents wished to continue managing their own monies, the policy would have no effect on them. However, if the residents wished to have friends, relatives, or the nursing home administrators manage their funds, they would have to sign form PWD 543: "Client Delegation of Management of Funds." Following the signature by resident/client, the adult service worker would file the form in the resident's service folder, give one copy to the nursing home administrator and one copy to the client. Hopefully the client could suggest a friend or relative who would accept this responsibility. The residents' friends or relatives would receive a letter from the adult service worker requesting them 
to volunteer to act as the residents delegate manager of the PIF. To implement this the congregate Care Consultant would have a form letter written that would ask for the friend's or relative's help and point out a few of the rules and procedures they would have to follow, such as:

1. Suching PWD 542--"Assumption of Responsibility for Management of Funds,"

2. Keeping a simple record of purchases,

3. Keeping all sales slips and receipts for three years,

4. Contacting the adult service worker before making a purchase of $\$ 50$ or more, and

5. If patient's funds accumulate to more than $\$ 75$, placing the excess in an interest-bearing trust account in Oregon.

The form letter was to be a friendly request to the friend or relative to help the Public Welfare Division in caring for the resident. The suggestion of regulations was to be alluded to but not made too specifically. A balance was to be struck so the request would be inviting yet honest in its approach.

The procedure for disseminating the letter required the chairperson to send it to the Public Welfare Division branches. The adult service workers would 
mail the letters from the branches to appropriate friends or relatives who are already managing residents' PIF, or might be open to the request.

It was suggested that at the time a friend or relative demonstrates interest in assuming responsibility, the worker could make a personal appointment with the individual to explain the regulations and procedures. It was further suggested that following the personal interview a second letter or information pamphlet be sent to the delegate.

As to follow-up information, the committee felt that the procedures and regulations should be outlined in a form similar to the following:

After the friend or relative signs PWD form 542-"Assumption of Responsibility for Management of Client's Funds, ,

1. Receipts and sales slips shall be saved for three years:

2. The funds shall be deposited into an interest bearing account when the total exceeds $\$ 75$. Amounts less than $\$ 75$ are retained in a safe place. At the friend or relative's discretion, an account may be opened for amounts less than $\$ 75$.

3. As under former regulations, the nursing home shall not charge against the Personal Incidental Fund 
any items that are included in the Nursing Home Guide under room, board, or necessary care.

4. For any single expenditure over $\$ 50$, the adult service worker shall be contacted for approval of the expenditure.

5. A quarterly accounting report shall be done on the PWD 713--"Patient Accounting Record." The form will be done in triplicate, the original for the delegate manager, the yellow copy for the resident, and the pink copy for the adult service worker.

The adult service worker will file the PWD 713 in the patient's service folder and will thoroughly monitor the file twice a year.

The committee felt that presenting the policy to the nursing home industry would be a most sensitive issue. It was decided that the first contact would be in the form of a letter outlining the new policy and enclosing the new forms. Following the letter, it was suggested the adult service worker explain the forms and procedures in greater detail as part of regularly scheduled staff appointments.

As the meeting was drawing to a close, the chairperson and the committee agreed that they felt positive about the new PIF policy. The committee felt they had finished revising the policy and after review by the 
Executive Committee, composed of the heads of the units of the Public Welfare Division, the policy would be ready to be sent to the State Printing office as revised. [Appendix E] The material would then be mailed to the nursing home facilities on January 1 , 1977. By March 15, 1977 the policy could be evaluated for its effectiveness. Copies of the policy's provisions for relatives and friends could not be mailed en masse as each resident's situation had to be considered individually by the adult service workers.

The Nursing Home Committee felt it had accomplished the first task on its agenda--the development of a new, protective PIF policy. Their next meeting was set for sometime after the first of the year, at which time they would continue to discuss problems and issues relative to nursing home residents.

As the newly-drafted materials were being reviewed it was recognized that two important steps had been overlooked. Both procedures were time-consuming administrative ones that must be performed before the material could go to the printer. It was hoped that the first procedure, which was a meeting between the PWD and the Oregon Health Care Association, could be accomplished within the next several weeks. By precedent the Public Welfare Division adult services and medical 
Assistance units meet with the representatives of the Oregon Health Care Association (OHCA) before the agency writes any policy which affects nursing home facilities' regulations or procedures. To facilitate such a meeting, the manager of the Adult Services unit immediately tried to contact the Executive Secretary of OHCA to set a date. It was one month before a mutually convenient date would be established. That date was January 13, 1977 .

The OHCA/PWD Meeting

The meeting between representatives of the Public Welfare Division and representatives of the Oregon Health Care Association took place the afternoon of January 13, 1977 in the state capitol. Attending the meeting on behalf of the Public Welfare Divison were the assistant administrator and a supervisor from the Medical Assistance Unit and the Congregate Care Consultant from the Adult Services Unit. The President and Executive Vice-President of the oregon Health Care Association represented that group.

The meeting was convened by the Manager of the Adult Services section of the Public Welfare Division. After introductions, the OHCA Executive Vice-President requested time for the President of the organization to 
to speak about charges which were appearing in the media in Multnomah County, which alleged nursing facilities' misuse of patients' funds. The President was anxious to deny the truth of these charges. He also outlined what he was doing at the present time to remedy the situation.

The Chairperson then introduced the task of completing a joint review of the drafted policy. The representatives of OHCA said they were prepared to request two specific changes in the policy:

1. When referring to the amount of money which must be put in trust, the wording "exceeding $\$ 75$ " should replace "\$75 or more." The Executive VicePresident felt that the term "exceeding" was more appropriate than "or more" because the latter required a stricter interpretation. He stated that the use of the word "exceeding" would allow for more flexibility.

2. Clarification of the option allowing a savings account to be opened for a resident before the sum of $\$ 75$ accumulated. The point the OHCA wished to make with this revision was that when a friend, relative, or nursing home administrator read the policy, they should understand that if depositing the entire PIF in an account for their resident was more convenient, such procedure was acceptable. 
The Executive Vice-President and President of the OHCA both stated that those were the only specific revisions they wished to see made at this time, however, they expressed general disappointment with the policy. Their disappointment touched upon three areas: those which were addressed in the policy, those which were not addressed in the policy, and one of a philosophical nature.

The area of their first disappointment, they said, involved the cost of the new policy to the nursing homes, specifically the loss of interest on the monies that the facilities would need to use as a revolving fund for the residents' PIF. If the patients' money had to be in interest-bearing accounts, the facility would be using its own money for the residents' immediate use. At the end of the month the facility takes its reimbursement from the residents' bank account.

The second area was that of unaddressed issues such as the revision of the "all-inclusive" rate. The OHCA representatives also felt that the policy should have specifically dealt with a re-evaluation of payment for medical supplies. They also included in their list of unmet issues the need to bond facility administrators. It had been their hope that the new policy would have a regulation requiring that every administrator be bonded. 
The final problem that the association had with the PIF policy appeared to be in the area of political philosophy. The Executive Vice-President requested that the policy cite the origin of the policy requirement that money be deposited in an interest-bearing account. He said OHCA could accept the policy if its origin, the Social Security Administration, was acknowledged. The association appeared to be scorning the authority of the state of Oregon, Public Welfare Division by accepting the policy as federal policy rather than state.

The Facility Certification Supervisor of the Medical unit offered to reply to one of the unaddressed issues that the association had listed--the problem of payments for medical supplies. Her reply was similar to the suggested sequence of actions which the Nursing Home Committee had proposed. The procedure as she outlined it was: (1) first the nursing home would notify the adult service worker that medical supplies were needed, (2) an investigation would be made to ascertain whether miscellaneous funds were available, and (3) failing that, the Branch would try to find money; (4) only if all else failed could the resident's PIF be used. The representatives of the association recognized this procedure as acceptable. 
In reviewing the policy, the OHCA representatives acknowledge that the nursing home administrator (or appointed staff) would be responsible for the following:

1. The nursing home would sign PWD 542--"Assumption of Responsibility for Management of Client's Funds, at the time resident has requested help managing their PIF by signing the PWD 543--"Client Delegation of Management of Funds."

2. Receipts and sales slips shall be saved for three years.

3. The funds must be deposited into an interest bearing account when the total exceeds $\$ 75$. Amounts less than $\$ 75$ are retained in a safe place within the nursing home. At the nursing home administrator's discretion an account may be opened for amounts less than $\$ 75$.

4. The adult service worker shall be contacted for single expenditures over $\$ 50$.

5. The facility shall submit the PWD 713-"Accounting Form" quarterly for each resident's PIF. The form shall be done in triplicate, one copy to the resident, one to the resident's adult service worker, and one retained by the facility.

6. The facility shall continue to consult the Nursing Home Guide for Personal Incidental Fund regulations. 
If a client appears to be unable or incapable of managing PIF monies, the adult service worker will send form PWD 544--"Physician's statement of client's Capacity to Manage Funds." To properly implement this policy statement the nursing home would adhere to the procedures by contacting the adult service worker in the following situation: If the physician decides the patient is incapable of managing his PIF or is incapable of delegating responsibility for the PIF, the adult service worker shall send the doctor PWD 544--"Physician's Statement of Client's Capacity to Manage Funds" and the physician must attest to client's inability to manage his funds.

The joint staff meeting had produced two revision in the policy, and the meeting had given OHCA an opportunity to express disappointment with the new policy; it had also given the Public Welfare Division staff an opportunity to clarify parts of the policy for the association.

The meeting was adjourned, agreement having been reached among those present that the policy would be sent out March 1, 1977 as interim policy for the facilities and that it would become an adopted public policy as of June I, 1977.

The first obstacle to implementing the policy 
had been hurdled. The second was to prove more complex.

Writing the Administrative Rule

The writing of an Administrative Rule was the second procedure which must be completed before the policy could be implemented. Administrative rule writing has become an accepted method of generating laws. The obvious advantages of this process of lawmaking lend it popularity. It is mechanically facilitated by established government process. Rules or regulations, administratively written, derive their authority from federal statutes. A rule is that which is of general interest and affects the average man; a regulation is more specifically targeted at the public who deal with government offices and bodies. Regulations are also written for internal use in government offices. (White 1948)

Oregon Revised Statute (ORS) 183.310 reads:

Rule means any agency directive, regulation or statement of general applicability that implements, interprets, or prescribes law or policy, or describes the procedure or practice requirements of any agency. The term includes the amendment or repeal of a prior rule...

The Public Welfare Division receives its legal authority to provide protection and services under Oregon Revised states 411 . In addition to responsibility for the provision of services, the Division 
has the further responsibility to,

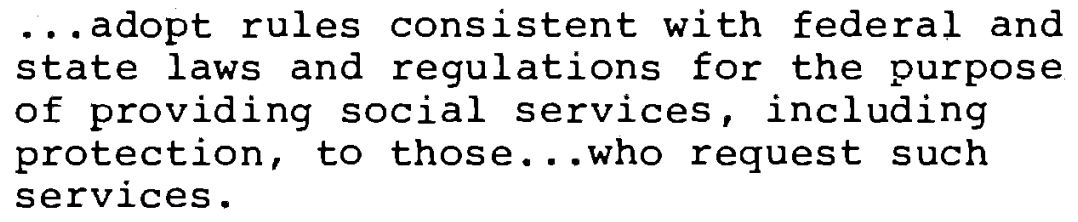

There are no specific statutory requirements dictating content or form of rule-making. However, the Public Welfare Division administrative suggestions do stress simple language, short sentences, and a conventional form.

At the time of completion the Rule will be submitted to the Assistant Administrator of the Public Welfare Division, reviewed by other assistant administrators, posted in the Branches for the staff to review, then reviewed and signed by the Administrator of the Public Welfare Division. A copy of the Rule is then sent to the secretary of state for filing. It could not be expected that the procedure would be finished before June 1, 1977 in time for the new policy procedures to be included in the staff manuals and the facilities guidebooks published by the state of Oregon.

The Rule was not filed in December as expected. As the need for filing the Administrative Rule was being addressed by the Adult Services Unit, another policy for nursing homes was being developed, one which did not involved PIF. This policy change for 
nursing homes was being written by the Medical Assistance Unit in reaction to a tragic event in Multnomah County. As a result of a complex situation involving the decertification of a nursing home facility, the transferring of residents from the home was followed by the deaths of some residents. Being responsive to the obvious need, the Unit wrote new policy procedures for transferring patients.

Apparently the issue of efficientcy and convenience led the administrative staff to decide that since so many policy changes for nursing home facilities were being written, it would be best to wait and file all administrative rules at one time.

Methods for disseminating the policy to the facilities was also being reconsidered. Until this time the state published guides for nursing facilities which categorized them according to the level of care they provided their residents (from complex medical procedures and services to simple services). Consequently there were guides for skilled, intermediate, homes for aged, etc. According to the Facility Certification Supervisor of the Medical Assistance Unit, the guides for skilled and intermediate facilities would be combined into one. The administrative rule would be filed in March and the PIF policy 
would most probably be published in the new combined guide, which was due on June 1, 1977.

Thus, the proposed PIF policy, drafted by the Consultant on Congregate Care, revised by the Nursing Home Committee, and reviewed by the PWD executive staff, which was to have been ready for implementation on January 1, 1977, would be delayed for six months. The delays that pushed the deadline from January 1 to June 1 appear to be a result of two considerations. The first of these was adrinistrative and the second was the Public Welfare Division's need to respond to the dynamics of the arena for which it is responsible. Responding to those needs impinged upon the agency's priorities. In spite of the PIF policy's position as a top priority for the agency in the summer of 1976, circumstances beyond the agency's control postponed the implementation for half a year. 
CHAPTER V

\section{AN ANALYSIS OF THE PROCESS}

OF POLICY DEVELOPMENT

Many authors of policy analyses offer efficient models in which policies can be studied and analyzed. In exploring the various models, Charles o. Jones' framework appears to be the most comprehensive and appropriate for analysis of the Personal Incidental Fund policy.

In conjunction with his model, the author posits some assumptions which he describes in his book, An Introduction to the study of Public Policy. There are six systems identified in his model for policy analysis. These systems include: Problem Identification, defining the problem and who is involved; the Formulation system acts to develop a plan for solving the problem, while the Legitimation system acts to conform to recognized principles and standards. The Application system deals with the administration of the policy and associated activities. The fifth system, Evaluation, is the judgment of the effects of the policy on public problems. While the last system, Resolution or Termination, is not appropriate for this study, it is an important system to identify. 
Jones admits a bias as to how policy ought to be made. His bias is that you must understand policy analysis before you can create policy. His work is based on an assumption of the importance of analysing how a policy has been made. It is also his assumption that only after you understand how the policy is made, can you determine how it ought to work. (Jones 1970)

\section{Problem Identification}

The first of the systems outlined in Jones' study is Problem Identification; activities that lend to the perception of the problem definition of the problem, aggregation, organization, and representation of information. The problems inherent in the state's PIF policy were of concern to the Public Welfare Division in 1975 as adult service workers and their supervisors told of abuse of patients' funds. By 1976, the special project "Personal Incidental Fund Account Audit Pilot Project" (Hawes 1976) pointed out major conflicts. In mid-1976 an impending court suit clearly identified some of the major misuses and abuses of patient funds. Administrators became increasingly conscious of the problem and defined the problem as one that needed solving.

The aggregation, those effected most by the problem, were the nursing home residents, approximately 
8,800 in number. These residents are represented at the policy-making level by the adult service workers, who link the public welfare department with the clients. The residents would have little access to the administration of the Public Welfare Division without these representatives.

The objective of the Problem Identification system is to indicate courses of action that will lead to the formulation of a policy.

The Formulation System of the PIF policy process began with the Congregate Care Consultant's original writing and development of the new policy procedures. These policy procedures were methods of alleviating some of the identified difficulties. Under the supervision of the Manager of Adult Services and in cooperation with the Public Welfare Division Medical Assistant, the plan for change was created. In the planning, feasibility was considered, bargaining anticipated, and revision expected.

The primary writer of the policy was sensitive to the issue of feasibility. She did not feel at any time that there were procedures that were unfeasible. With the exception of the PWD Form 542--"Physician's Statement," that assumption proved to be true. Segments of the policy are difficult to carry out but remain feasible. It was anticipated the bargaining activities 
would be primarily with the Oregon Health Care Association. This part of the process was successful and their approval of the policy was obtained. Timing helped bring about the success of the bargaining with the Association. The negotiations were concurrent with an expose by the media of alleged abuse of patients in a Multnomah County facility. Furthermore, the Oregon State Legislature was in session and strong legislation was being written to monitor the industry. The Public Welfare Division at this point appeared to be a lesser threat to the independence and community acceptance of nursing facilities than the legislature and public opinion. Revisions of policy are a common occurrence, until the document actually reaches the printer. The PIF policy and procedures were no exception. The Nursing Home Committee made revisions, workers in the field sent in suggestions for revisions, and the OHCA made their objections. Each change, it was hoped, created a greater acceptance of the policy by interested parties.

\section{The Legitimation System}

The Legitimation System is identified by Jones as an essential segment of the policy-making process. In major national policy-making, this system "legitimates the basic political process... [which] is dependent 
on the granting of legitimacy by a people to government." The sources for legitimacy in this case are various significant publics and the government. (Jones 1970) The scholars of policy analysis stress the importance of the legitimation system. Also stressed is the need to make sure that the political majoirty is secure while support is being gathered. In national policy, the system is complex and difficult to analyze.

However, since the PIF is only a state policy issue, the legitimacy system is somewhat easier to identify. That is to say, for this policy the authority was clearly defined and the needed support groups easily identifiable. The power and authority to write the policy was granted to the Public Welfare Division by the Legislature. Oregon Revised Statutes (ORS 183.310) allows the agency to write policy in the form of Administrative Rules, i.e., any agency directive, regulation, or statement. Since the goals and objectives of the new PIF policy were to protect the client, the legitimacy lay in the agency's authority to provide this service under oregon Revised statutes $\$ 411$.

Exercising the authority conferred upon it through the established legislative channels, the Adult Services Unit of the Public Welfare Division delegated to the Congregate care Consultant authority to begin writing 
new procedures which would protect the residents in nursing facilities and would be acceptable to the various significant publics.

To accomplish this, Jones would insist, it is necessary to build a majority and a support base. Although there was no formal voting majority who must accept this policy, it was still necessary to build a majority in its favor among the different "publics" involved. With majority approval, it was felt that support would grow for the new policy. The majority building and support build phases of this system began with the Congregate Care Consultant's convening of the Nursing Home Committee, representing every group within the Public Welfare Division which was involved in the PIF issue: field staff, supervisory staff, branch level administrators, state level administrators, consultants, field operations staff, and M/IPR Team members .

The branch adult service workers' approval was in many ways the key to support building since the adult service workers on the committee represent several hundred workers who have nursing home residents as clients. Using the field staff as representatives to the policy-making body enhanced the probability of its acceptance by other field staffs. They are, after 
all, the ones who execute and monitor the policy procedures. Soliciting their views in order to gain their support was an important step to legitimizing the policy.

The second group from which the PWD hoped to gain support was the Oregon Health Care Association, representing approximately 150 of the 200 nursing home facilities in Oregon. Although the organization is 27 years old, with advent of the federal Medicare and Medicaid programs, it had grown to be the major representative of the industry in oregon. The Executive Vice-President maintains an active role in lobbying and negotiating with the Public Welfare Department in the state capitol.

A meeting with the OHCA representatives was held in the state capitol before the policy was finally approved. The primary goal of the meeting was to build support for the policy with these representatives of 80 percent of the industry. At the meeting the OHCA made several revisions in the policy. They wished to be on record as saying, however, that they would accept the policy not on the authority of the state's interpretation, but because it came out of federal guidelines. They were accepting the policy and supporting it with their majority leadership, as a federal regulation not a state one. 
The OHCA was exemplifying an old problem in policy development--the challenge to the writer's legitimate authority. The private enterprise system of the Health Care Association is at odds with the state's power to control them. In this issue the Association felt it necessary to reassert its philosophy. Pitkin states that the conflicting values in a democracy create situations where legitimacy may often be "in the eyes of the beholder." (Jones 1970)

In order to maintain existing support, the Public Welfare Division staff chose not to debate its authority to write policy procedures with the representatives of OHCA. Jones asserts that the policy process should be analyzed with an awareness of such exchanges and adjustments. The PWD was able to accept an affront to its legitimate authority, in exchange for OHCA's minor revisions and their promise to implement the policy. The output or product of the preceding systems is a policy or course of action. How the policy will be applied and administered will foreshadow the policy's future effectiveness. The PIF policy, along with many nursing home policy regulations, was written as an Administrative Rule. This style of policy writing is not unusual. After a legislature has passed a law and appropriated funding, it can then direct the agency to 
determine what problems exist, formulate a plan to ameliorate the problems, and set legitimate procedures to carry the policy out. (Jones 1970)

Alan Altschuler discusses several points relevant to this process:

1. A high proportion of all statutes originate in the bureaucracy.

2. Politicians charged with evaluating legislative proposals typically rely heavily on bureaucratic advice.

3. Bureaucrats are extremely active "sellers of ideas" to both elective policy makers and to the general public.

4. Most laws leave room for a wide range of interpretations and the courts typically treat administrative interpretations that are remotely plausible as authoritative. (Jones 1970)

This small local segment of the larger national Medicaid policy, reflects Alan Altschuler's point. The necessity of re-writing present PIF policy was largely the result of the vagueness of prior interpretations, and the Public Welfare Division in Oregon hoped finally to prevent the perpetuation of regulations that left the resident unprotected.

In the application and administration of this policy, many factors would be involved, although the 
policy in no way directly changed the bureaucratic structure of the Public Welfare Division. An "old-line agency" continued to administer interpretations of policy as they are introduced over time. As in Jones' formulation, no major shift in the structure or status of the agency had occurred. (Jones 1970)

Concurrent with the Adult Services Unit's activity to change the policy, the Medical Assistance unit was changing another segment of PIF policy. This segment of PIF policy fell within their area of responsibility and concerned the facilities' billing the residents for services or items that were paid by the state (Vendor Payment). The Medical Assistance Unit was also writing policy delineating proper procedures for bringing charges against a facility or delegate manager for abuse or misuse of residents' personal funds. The activities of the two division within the Public Welfare Division were never in conflict, nor were they synchronized, until both policies were presented as a unit as the Public Welfare Division statewide training day in February 1977.

In all probability, if the two division had worked together their own segments of the policy would each have been implemented sooner. Because they did not write it together, the Adult Services unit wrote the 
protective segment and the Medical Assistance Unit wrote the abuse and alleged fraud segment of the new PIF policy.

Review by the executive staff of PWD is mandatory before a policy regulation can be approved and sent out for implementation in the field. The executive staff includes the heads of the PWD units involved in the policy writing activity. For the PIF these were the Adult Services Unit and the Medical Assistance Unit. It was at the Executive staff Meeting in early December, 1976 that writing of an Administrative Rule was first discussed. As a result, the proposed policy was not written as an Administrative Rule at that point in time. The delay in application of the policy was three months for some segments of policy and six months for others. One segment of PIF policy, delayed three months, was the publication procedures for the friends and relatives who would accept responsibility for residents' funds. The policy was to be announced to these delegates by a form letter written by the Congregate care Consultant. The letter would be sent by the branch office adult service worker to the clients. (Appendix B) The adult service worker was to interpret the information in the letter for the friend or relative and answer any questions they might have. 
Another section of the new policy, held up for six months, was the segment involving the nursing home facilities. The delay was prolonged by the agency's decision to revise both the Intermediate Care Facilities Guidebook and the Skilled Nursing Home Facilities Guidebook into one document. Therefore it was decided to hold the PIF policy procedures up until the new Guide for Nursing Facilities was published in June, 1977. To prepare for implementation of the new procedures, a training session was planned. Originally, the Congregate Care Consultant was to visit different cities around the state and introduce and interpret the new policy for branch managers and adult service worker supervisors .

The actual training was done at a two-day workshop composed of branch managers, supervisors and some adult service workers. The total amount of time spent on the interpretations and explanations was two hours. (The training session had many implications which will be discussed in the Evaluation section of this chapter.)

Analysis of administration and application of the PIF brings up the subject of "mutual role-taking" and "empathy." (Jones 1970) Out of the roles of enforcer and enforcee come "the rules as actually acted out: the specification of the loopholes, penalties, 
and rewards that reflect an acceptable adjustment of these incompatible roles." (Jones 1970) The role taken in this instance by the adult service workers, the supervisors and the executive staff of the PWD was the "enforcer" role. They were to have empathy for the enforced, the friend, relative, and nursing home people who would be most affected by the procedure. ...so far as the great bulk of law enforcement is concerned "rules" are established through mutual role-taking; by looking at the consequences of possible acts from the point of view of the tempted individual and from the point of view of the impact of his acts upon the untempted. The result is a set of unchallenged rules implicitly permitting evasions and explicitly fixing penalties. Administrators are thereby able to avoid the sanctions of politically powerful groups by accepting their premises as valid; while at the same time they justify this behavior in the verbal formulas provided in the rules. (Jones 1970)

The application of the PIF policy began on the assumption that the policy was an enforcable set of procedures and regulations. However, some segments appeared weak and vulnerable. The weakest and most vulnerable was that section which provided for management of patients' funds when the patients were unaware of the need for delegated management. (Appendix E)

The actions of the PWD at this point significantly predicted the effectiveness of the policy on the public. Response to a new policy for an old problem will 
be one of two reactions: support or demand for adjustment of the policy. This policy encountered both responses. In evaluating the PIF policy we will look to see what the reactions were. Evaluation must be understood as that process which judges the wroth of the policy in light of its ability to solve the problem to which it has been addressed. Variables that can be used to judge any policy's wortin include "relief for publics, costs involved, and political support." (Jones 1970) The adult service workers' responses were solicited at a small group meeting in February, 1977 at the East Portland Branch Office. This Branch has approximately 20 percent of the state's facilities under its aegis. Four adult service workers discussed the new policy and some representative reactions in support were:

1. The policy was much needed.

2. Whatever weaknesses it has, the strength lies with the protection the policy provides the resident. (Fay 1977)

Some adult service workers wanted changes in the proposed policy, for example they (a) felt the policy placed a great burden on the worker, therefore additional staff might be written into the policy, specifically auditors; (b) wished to see stricter enforcement of written policy. (Fay 1977) 
The Oregon Health Care Association representative asked for several changes but on the whole supported the concept of a clear and effective policy.

Using the variables Jones suggests, we can write a mini-evaluation of the policy involving residents' friends and relatives, keeping in mind that it has only been implemented for six weeks, and therefore any judgments are subjective based on reports of reactions of the adult service workers. The segment of policy procedures involving nursing facilities has been in effect for only six weeks and the judgments upon this segment are likewise subjective reactions from a few Association representatives. The relief to the public can be judged by its effectiveness. The effectiveness of PIF policy is as yet unknown. The largest population, the dependent residents in nursing facilities, will only indirectly know of the new regulations to protect their monies. There has been no communication to the effect that the PWD has been active on their behalf.

The residents' friends and relatives have been notified and petitioned to help implement the policy. The policy does provide that they shall be given instructions and help. To facilitate this, a handbook will be provided (Appendix A) and the adult service 
workers will be available to the friend or relative who has questions.

Relief to the industry's problems varies. For the facilities who mismanage funds unintentionally this policy will be helpful. It has clearly written regulations on how to manage, account, and deposit the residents' money. The dishonest facility which has seen the residents' funds as a source of money for making up discrepancies in the budget will now have to be more obvious.

For the Public Welfare Division adult service workers, the policy, it is hoped, relieves them of the role of "enforcer" of vague rules and regulations. This policy is clearer and more precise and much sounder than anything the worker had before to protect the residents' funds. The worker is relieved of individual decision-making responsibility and crisis response. The variables of cost must include a discussion of the question, cost to whom? The cost to the state of Oregon will be indirect. There are no plans to hire additional adult service workers to monitor the quarterly accounting forms, seek out appropriate friends or relatives to be delegate managers, or answer the public's questions about specific PIF cases. The cost to the state will probably be indirectly paid by still greater 
turnover in adult service workers, undone tasks, incomplete record keeping. The greatest cost will occur with perfunctory monitoring of the PIF accounts. It appears that the highest price will be paid by the adult service workers, who add this additional task to already unrealistic caseloads. There is nothing they can drop from their work assignments and now they must add the PIF tasks. These costs to the individual service worker make one conclude that there is little chance that the accounts will be properly monitored by the adult service workers, or that friends and relatives will be given the time they need for interpretation and explanation of the policy. The nursing home administration stated that the cost of bookkeeping for them will be high and will cut into financial profits. In reaction some facilities in Multnomah County, upon hearing of the proposed policy, have announced they will not continue to manage or handle patients' personal funds.

The cost to the relatives and friends will be in time. They will have to fill out forms, keep a running account of expenses, and, possibly open a bank account for the resident if the funds accumulate. Jones suggests that political support is yet another 
variable that would aid in evaluating policies. However, for the purpose of evaluating the PIF policy, this aspect is, as yet, insignificant.

The last variable for evaluation is the category of problems created. Initially we learned that "policy makers are not faced with a given problem" but rather as one problem is solved it is common for many others to emerge. (Jones 1970)

The problems created by the PIF policy include:

1. Heavy work burdens on the adult service workers.

2. Additional expense for most facilities in providing bookkeeping services for residents.

3. Facilities stated intent to write into their admissions policy that they will not accept the responsibility for any resident's personal incidental monies.

For family-less and friendless residents there will be need for legal conservatorships.

4. The PWD 542--"Physician's Statement of Client's Capacity to Manage Funds" has no firm legal precedent and some workers feel that the form is not legal.

Problems will be seen to fall into two categories: those that can be solved by changes in existing policy and related problems that become identified. (Jones 1970) 
As these other problems emerge and become identified they will have to be processed. Each category of problems is processed differently. The problems that can be changed by incremental changes in the policy are shown in the schematic drawing below:

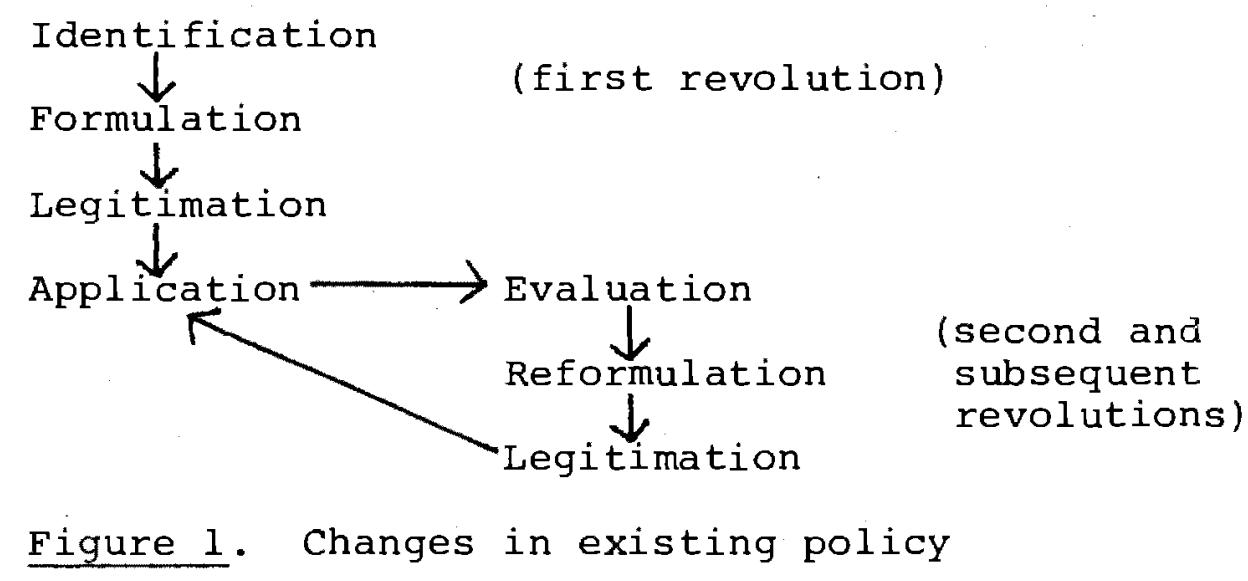

The associated problems which emerge and become identified after the policy is implemented can be seen in Fegure 2.

One of the amazing weaknesses in much contemporary public policy making is that there is no systematic learning from experience. Very few evaluations of the real outcome of complex issues are made, and there are even fewer on which improvement of future policy making can be based.... In spite of the common tendency to justify action in terms of "experience" the simple fact is that learning from experience is accidental and sporadic. (Jones 1970) 


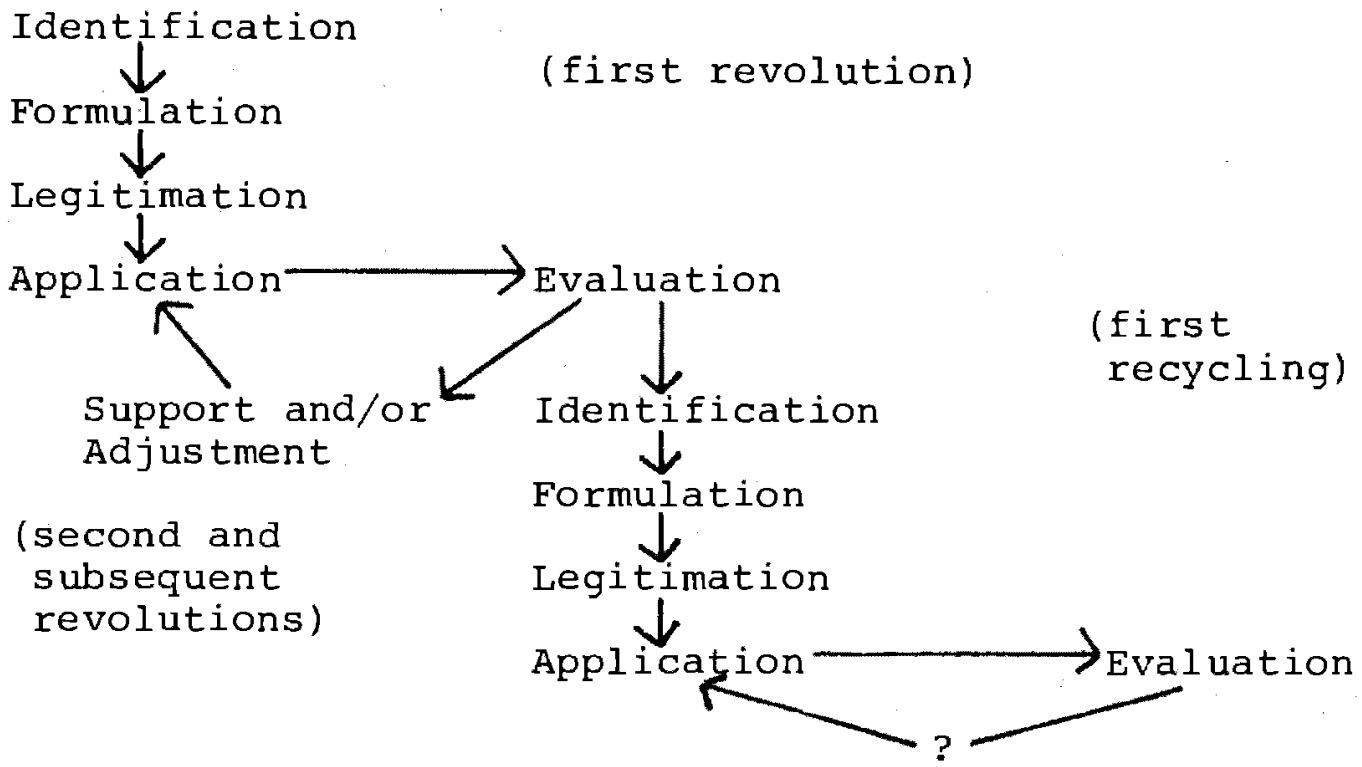

Figure 2. Identification of other problems

The final element of Jones' framework is the problem resolution or change phase. It is too early to see the resolution and termination process in action with regard to the policy under discussion. 


\section{CHAPTER VI}

\section{BARRIERS TO IMPLEMENTATION : \\ SOME OBSERVATIONS}

In this chapter a description of the organizational network affecting the formation and implementation of the Personal Incidental Fund policy will be made. Following the description, some suppositions as to the causes for the delay in the policy's release will be set forth, as well as possible barriers to the policy's future effectiveness.

The major affective agents in the network of organizations and individuals involved with the policy are the Public Welfare Division and its two subunits, the Adult Services Unit and the Medical Assistance Unit. Their activities are focused upon the resident, who has a client relationship to the organization. The only confederation in this network, the oregon Health Care Association, represents the bulk of the nursing home industry. (Some nursing homes are not affiliated with the OHCA and enter the network as separate organizations.) Relatives and friends of residents enter the network, like the PWD client, as individuals. 
Each component can be examined in light of the following elements: (1) manifest goal, (2) general activities, (3) specific activities relative to the PIF policy, (4) linkages, and (5) latent goal. The manifest goal is the formal public goal of the component. Linkages between agents are either formal or informal. Formal linkages are memoranda, directives, referrals, confirmed telephone conversations, Nursing Home Guides, and contracts. Informal linkages are contacts made through ad hoc meetings, mutual friends, shared research, or personal relationships. The latent goal of a component is defined as one it pursues in a less overt manner than its manifest goal. (Rothman 1974) Each component is assumed to have a manifest goal and a latent goal.

\section{TABLE I}

DESCRIPTION OF COMPONENTS

\section{Public Welfare Division Administrative Staff}

Manifest Goal:
To provide for the physical and psychological well-being of the state's dependent citizens. To write policy and thus establish programs and social services necessary to effect these goals. 
General Activities:

Activities Specific to PIF :

Linkages :

Latent Goal:

Client (Resident)

Manifest Goal:

General Activities:

Activities Specific to PIF:

Linkages :

Latent Goal:
1. Administrative Rule and Regulation writing.

2. Administration of programs.

3. Convening joint meetings with outside organizations.

4. Supplying government and legislative staff with data.

All the above.

1. Governor; Formal \& Informal

2. Legislature; Formal \& Informal

3. PWD subunits; Formal \& Informal

4. Clients (residents); Formal

To function efficiently within a given budget in order to assure the Legislature's continuing support and the organization's survival.

To receive adequate health and medical care and to maintain a sense of worth and dignity.

To request services.

To delegate the management of the Personal Incidental Funds by signing form PWD 543 or to self-manage PIF.

1. PWD; Formal

2. Nursing Facility; Formal \& Informal

3. Friends and Relatives; Formal \& Informal

4. Adult Service Worker; Formal

To be able to purchase personal items to enhance well-being. 
Adult Service Worker (PWD Sub-Unit)

Manifest Goal :

General Activities:

Activities Specific to PIF :

Linkages :

Latent Goal:
To provide for physical and emotional well-being of resident.

1. To provide services to enhance the quality of residents' lives, their socio-emotional needs.

2. To jointly plan for residents with the facility.

3. To advocate on behalf of residents.

4. To provide information and referral services.

1. To help residents find appropriate delegates.

2. To file PWD 713 accounting forms quarterly and monitor them twice a year.

3. To act as resource person for family, friends, or facilities concerning residents' PIF.

1. PWD; Formal

2. Medical Assistance Unit; Formal \& Informal

3. Nursing Facility; Formal \& Informal

4. Resident; Formal

5. Residents' Friends \& Relatives; Formal

To fulfill responsibility to residents while maintaining personal health and well-being.

Medical Assistance Unit (PWD Sub-Unit)

Manifest Goal:

Proper management of Medicaid policy and programs. 
General Activities:

Activities Specific to PIF :

Linkages :

Latent Goal:
1. Administration of all programs.

2. Policy writing.

3. Monitoring care vendors.

4. No direct contact after eligibility is established.

1. Writing regulations.

2. Referring problems to Medical Utilization Unit.

3. Conducting yearly monitoring of PIF by M/IPR Team.

1. PWD; Formal \& Informal

2. Nursing Home Industry; Formal \& Informal

3. Client (Resident); Formal

4. Adult Service Workers; Formal \& Informal

To maintain mutually acceptable relations with the nursing home industry.

Nursing Home Administration

Manifest Goal:

General Activities:

Activities Specific to PIF :
To provide residential care and medical services to fill the needs of each resident.

Daily involvement.

1. Are discretionary.

2. If facility accepts responsibility for managing PIF they must deposit funds in excess of $\$ 75$ in an account.

3. Facility accounts for funds, dispenses funds per daily requests.

4. Makes quarterly reports to PWD adult service workers and residents. 
Linkages :

Latent Goal:
1. PWD; Formal

2. Adult Service Workers;

Formal \& Informal

3. Resident (client); Formal \& Informal

4. Residents' Family \& Friends; Formal \& In formal

To run facility at maximum profit.

Residents' Friends and Relatives

Manifest Goal:

General Activities:

Activities Specific to PIF:

Linkages :
To facilitate the residents' use of their PIF money thus enhancing the residents' quality of life.

1. Are discretionary.

2. Upon consent, cooperate with the PWD in many aspects of residents' care.

1. Sign PWD 542 to accept responsibility for PIF.

2. Keep a monthly accounting of monies on PWD 713 and forward the form quarterly to resident and adult service worker.

3. Keep all receipts for purchases for three years.

4. Contact the adult service worker to confirm purchases over $\$ 50$.

5. Deposit funds exceeding $\$ 75$.

1. PWD; Formal

2. Residents; Formal \& Informal

3. Adult Service Workers; Formal

4. Nursing Facilities; Formal \& Informal 
These components constitute a very complex system and all elements of this system were instrumental in the development of the PIF policy and procedures. Since each of these components has a different manifest and latent goal, diversity produces contending forces which may be barriers to any organizational task. To further complicate the system, each component has a wide variety of activities; in some instances one component's activities can create barriers to the other's activities and goals.

Following are certain suppositions that can be made about the policy writing process. There are also suppositions that can be made about the problems, relationships, and conflicts that will create barriers to the policy's effectiveness in the future.

\section{DIVISION OF LABOR}

When two or more sub-units of an organization work independently on sections of a project, lack of coordination can be expected. Consequently, the way an organization delegates tasks to its sub-units may produce constraints and barriers that will inhibit the organization's output. (Hall 1970)

As problems relative to the Personal Incidental Fund policy arose throughout the state they were 
designated according to whose domain seemed appropriate, to the Medical Assistance Unit or the Adult Services Unit. The Medical Assistance Unit accepted those problems involving use of residents' funds under the "all-inclusive rate" set by the state. If the problem had nothing to do with medical services, supplies, or equipment, the adult service worker brought the issue into the Adult Services Unit's domain for solution. Thus, the residents' needs were perceived as distinct entities--medical needs and socio-emotional needs-corresponding to the division of labor in the main organization.

When administrators assigned the task of creating new policy to eliminate the prevailing problems, the existing division of labor prevailed. The Congregate Care consultant wrote policy for non-medical issues and the supervisor of the Medical Utilization Unit wrote policy procedures relative to medical issues. Each carried out responsibilities within the sub-unit and within his or her own domain. Neither the activities nor their timetables were coordinated. In early December of 1976, the Adult Services Unit's segment of the policy was completed, it was being held pending publication of a new vendor guide in June, 1977. For the Adult Services Unit this was to provide an 
unexpected delay in issuance and implementation of its policy. Thus, the uncoordinated activities caused by specialization, oriented by the division of labor within the PWD, created a barrier to the timely implementation of the PIF policy.

\section{REQUIRED INFORMATION}

It is impossible for one individual within an organization as large as the Public Welfare Division to have adequate knowledge and information to successfully develop, write, and implement policy. The congregate Care Consultant's formal linkages to the PWD did not adequately prepare her for the task of policy writing. These linkages included manual regulations and her superiors' and colleagues' expertise. Nor did her informal linkages via conversations with colleagues or interdepartmental memoranda give her the knowledge she needed. The scarcity of information and knowledgable sources appears typical of such large organizations.

The three major issues of which this policy writer was unaware as she readied the policy for the printer were (1) the necessity for setting up a joint meeting with the Oregon Health Care Association to review the new policy. (This procedure had been established by precedent rather than written regulation.) 
(2) The need to write the new PIF policy and procedures as a state Administrative Rule. (3) The status of the Medical Assistance Unit's segment of the policy. (Significantly, she did not know the Medical Assistance Unit's segment of the policy would create a barrier to implementing the policy as developed.) Lindblom points out that "most decision making is based on very little information and poor communication." (Jones 1970) There are many reasons policy makers find themselves in such inauspicious circumstances. One reason is, as Lindblom points out, that no individual or group of individuals can develop the wealth of knowledge or scope of information necessary to write a complete policy.

In the case of the Personal Incidental Fund policy, the size of the $\mathrm{PWD}$, with its complex administrative procedures and unwritten precedents created a delay in the implementation of a much-needed policy.

\section{INTERACTION}

The dynamic nature of the network involved in writing the new Personal Incidental Fund policy created a barrier to the policy's implementation by the facilities. Had the Congregate Care Consultant been able to "freeze in time" all the components of 
the network while writing the policy, she might have been able to meet the January 1, 1977 deadline. However, she had no control over the actions of residents, facilities, adult service workers, the Health Division, the Medical Assistance Unit. The dynamic nature of the components within the system created situations, actions, and reactions that caused the delay.

Situations occurring while the policy was being written included a precedent-setting court trial, with public charges of neglect and irresponsible behavior leveled at one facility, the PWD, and the Health Division. The Attorney General's Office became involved, Concurrent with all this, the Gray Panthers, a senior citizens' activist group, focused public interest on issues relevant to the Public Welfare Division organization and the nursing home industry.

The most immediate and dramatic situation to occupy the attention of the PWD and the public, involved residents being moved from a decertified facility. In the aftermatch of the move, charges were brought that residents had been fatally traumatized in the process. Charges of irresponsibility were made against all involved. The Public Welfare Division reacted to these charges by re-examining the policy for transferring residents from decertified homes. The Medical Assistance 
Unit was given responsibility for the task. Writing the PIF policy was set aside in order to write and issue this crucial policy which involved residents' physical well-being and maintenance of life. Often in policy writing conflicting values are involved which made setting priorities difficult. (Lindblom 1968) However, in this case the Medical Assistance Unit's priority was clear cut--public pressure demanded that the PIF policy writing be delayed until the more important policy for transferring residents was completed.

The need to rewrite policy and procedures concerning transferring residents made the need to completely revise the guides more apparent. Thus, it became almost certain that the segment of the PIF policy relative to nursing facilities would not be issued until June, 1977, or at the time the new guides were published.

\section{BARRIERS TO EFFECTIVE POLICY}

Incongruency of components' goals within a network will create barriers to implementing policy. The latent goal of the nursing home facility component in the network is to receive maximum profit from investments, while one latent goal of the Public welfare 
Division organization is to control that profit.

With the exception of a few non-profit nursing facilities, nursing homes are operated on a profit basis. The facilities operate with the manifest goal of providing care and services for their residents, but their established latent goal is to operate their businesses in order to receive maximum profit--a goal not inappropriate in a free enterprise system.

The latent goal of the Public Welfare Division's administration is to meet the needs of its clients with the least possible tax dollar expenditure. To accomplish this goal the division sets a formula for determining payments. The formula is based on the level of care the patient needs, including special services. Therefore a facility may receive $\$ 12$ per diem for one resident and $\$ 19$ for another.

Although these private businesses cannot by regulation receive their established commercial rate from Medicaid residents, there are no limits set as to what they can charge their "private" residents. Private residents pay the facility out of personal or family funds. A case in point: the rate charged by a private home for the aged in Lincoln. County is $\$ 300$ per month per patient, but the PWD will only pay them $\$ 245$ per month--82 percent of their desired rate. 
As a result, some facilities limit the number of their residents who receive Medicaid funds.

The Oregon Health Care Association represents a federation of 80 percent of the nursing home facilities in the state. This federation has continually worked to revise the profit-limiting "all-inclusive rate" and provide the facilities with opportunities to increase their profits while caring for PWD dependents who receive Medicaid funds.

\section{POLICY FORMULATION VS. GOALS}

Incongruity exists between the manifest goals of the Public Welfare Division and its choice of a policy formulating process for the Personal Incidental Funds. This incongruity may create yet another barrier to the successful implementation of the PIF policy. The manifest goal of the PWD is "To provide for the physical and psychological well-being of the state's dependent citizens. To write policy and thus establish programs and social services necessary to effect these goals." The choice of a policy formulation process based on the value of professional expertise eliminated the client's input.

Three styles of policy planning and formulation are based on competing value orientations. (Gilbert \& 
Specht 1974) The first is the leadership type of policy formulation process. The leadership is either natural or elected. The second type of formulation process is that chosen by the PWD, i.e., the expert as policy developer. This is the formulation based upon the valuing of meaningful contributions of participants. Without this information, the residents are likely to feel that the policy results in just one more element in their environment over which they have lost control. Someone "out there" continues to control their lives. The residents' dependency is reinforced by a communication system that has no comprehensive linkage between resident and the PWD organization.

Each method has its advantages and disadvantages for application to the PIF policy. The greatest advantage of the leadership type of policy formulation is that it comes with built-in legitimacy. For a heterogeneous network such as the one involved in the PIF policy formulation, the disadvantage of using this process is that the competing goals of different agencies could create unending debate and conflict on every policy issue. (Gilbert \& Specht 1974) In the past, applying this process has brought chaos.

The choice the PWD made was based primarily upon the value of expertise-oriented policy-making. A 
specialist was chosen to do the task. The advantage of this formulation process is the opportunity to use the available knowledge and experience of one who has professionally specialized in the appropriate area. It is an efficient and expedient method to choose. The specialist was chosen to write the policy; she in turn called upon specialists within the PWD organization to help her revise the first draft of the policy. The leadership of the Oregon Health Care Association was later called in to review the policy, thus affording input from another component of the network. The major component of the entire network-the resident--was not represented on the Nursing Home Committee, nor was their input formally solicited by the policy writer. The limiting of participation to the specialists, with a minor participation by the confederation of nursing homes, illustrates the incongruity between the manifest goal of the PWD and its choice of a policy-making process.

A third recognized method of policy formulation involves all the components affected by the PIF policy. Its advantages are reported in a study which found that when people participate in the policy-making process they feel more positive about the policy and more closely associated with others in the network. On the other hand, 
those who do not or cannot participate feel apathetic, indifferent, and alienated. (Gilbert \& Specht 1974) Therefore, a policy written with the greatest amount of participation has the greatest likelihood of benefiting those it affects and of being well received by all of the network's components. One disadvantage is that this method is a more time-consuming and difficult task.

The case study of the PIF policy demonstrates that, although the process that the PWD chose was primarily based on valuing expertise, they also used an element of the leadership process. However, they completely overlooked the residents' participation in all this.

The new policy perpetuates the communication gap between the PWD and the resident. In addition to purchasing needed items, PIF money could provide the resident with the sense of self-esteem which accrues to a person with private funds; such money could engender a sense of autonomy as the resident makes choices concerning the spending of it. Without the dignity that results from self-esteem and autonomy, the resident incompletely benefits from the PIF monies. The residents' input must be solicited and valued to attain the goals of the policy and new policy information must be explained directly to the resident immediately upon its release. 
Following the joint policy review, a formal release of the policy was made to all components in the network. Facilities within the OHCA heard about it in the OHCA Newsletter and at the meeting; nonaffiliated facilities received letters from the Public Welfare Division explaining the proposed policy. The guide books using the new policy were released before July, 1977. The adult service workers saw copies of the newly released policy at their branch offices. The adult service workers mailed letters to the friends and relatives concerned before April. There was just one component left out of the formal release of the policy--that was the resident.

The residents were to have the new policy informally explained by their adult service workers at the time of their regular visit. (By regulation, the adult service workers must visit the residents two times a year.) No formal letter was sent to residents advising them of the new policy.

\section{COMMUNICATION}

Discontinuity exists in the communication system between the PWD and the residents concerning the Personal Incidental Fund policy. The problem is exemplified by two major gaps in the patients' understanding of the 
basic principles of the new policy and procedures. The discontinuity of communication inhibits one goal of the policy--that which seeks to facilitate the patients' sense of self-esteem, autonomy, and dignity. Some adult service workers and private social workers who are employed by the nursing homes question whether the residents have ever been made fully aware of their entitlement to personal funds under Title XIX. Some may have been given the information during a harried intake process but the information has not been reinterated.

In the case of the Personal Incidental Fund policy the conflict between the latent goals of the organization and those of the individual adult service worker interferes with implementation of the policy. Thus, as long as constituents measure the efficiency and effectiveness of the Public Welfare Division by its stringent budget regulations and scant staffing patterns, the conflict between the goals of that agency and its workers will continue.

\section{INTRA-AGENCY CONFLICT}

In some instances the latent goal of the organization is not the same as the latent goal of its sub-unit members. The administrative staff's latent goal is to present a public image of an efficient and frugal agency. 
The Public Welfare Division is responsible to the Human Resources Department of the state, which is in turn responsible to the Governor. The Governor is responsible for submitting to the Legislature a budget representative of the Public Welfare Division's needs. Thus, the agency's allocation is dependent upon the Legislature. They, in turn, are reactive to their constituents. Therefore, prudently, the PWD continually measures the reactions of the constituents to their policy and program. The constituents seem to react favorably to low costs and scant staffing in governmental agencies. A process of stringent allocations results. Consequently the PWD must write policy and programs expeditiously rather than ideally.

It would appear that until a resolution of the conflict between the Public Welfare Division's goals and the industry's goals can be made, such conflict will constitute a barrier to effective functioning of the Personal Incidental Fund policy. As a result, there exists a great deal of confusion concerning the source of these monies and the items that the monies can be used to purchase. Many residents assume that the facility has been kind enough to purchase the items, others believe that a generous relative is their benefactor. The misconceptions created by the communication 
gap does little to enhance the residents' well-being. The adult service workers are the organization's closest link with the residents. The adult service workers' manifest goal is to provide for social and emotional needs of residents and monitor their care at the facilities. Their duties under the new PIF policy add burdensome responsibilities. The procedures are time-consuming for these workers, who already feel overwhelmed by their workloads.

The adult service workers perceive protection of the patients' PIF monies as lying within their domain of responsibility. Some, however, feel the policy is unfeasible under present conditions because the new tasks generate an overwhelming amount of physical and psychological stress. (Fay 1977)

To ensure the survival of the Public Welfare Division organization, stringent staffing ratios at the branch field offices are maintained. Survival must be accepted as an organization's legitimate goal. (Lindblom 1968) However, conflict may result when members of the sub-unit of the organization (in this case the adult service workers) have individual survival as their goal. 
CHAPTER VII

CONCLUSION

While the policy-making process is in fact ongoing, for the purposes of our conclusion, we will consider the beginning of the planning process, the first meeting of the Nursing Home Committee. The committee joined the Congregate Care Consultant in order to create policy and procedures that would eliminate abuse, misuse, and misunderstanding of the Personal Incidental Funds of the nursing facility residents.

It will be recalled, that the committee at its first meeting listed six barriers to the effective and efficient delivery of services to nursing home residents. They included:

1. Inadequate staff of adult service workers at branch offices;

2. Lack of residents' involvement;

3. Lack of communication and coordination within the Public Welfare Division;

4. Inadequately trained nursing home staffs;

5. The adult service workers' lack of up-to-date guides and memoranda at the branch offices;

6. Conflicting regulations from various sub-units of the Public Welfare Division. 
Following the listing of the barriers the committee proceeded to develop the new PIF policy. In this process these well informaed, well meaning policy developers perpetuated two of the old barriers to effective service delivery; three of the listed barriers were addressed and eliminated in varying degrees, while only one barrier was completely eliminated in the development of the new policy relatives to the residents' PIF.

The committee had pointed out that inadequate staffing of local branches of the Public Welfare Division made the adult service workers' tasks impossible to perform in any depth. Yet the new policy places further burdensome tasks and paperwork upon the worker. The committee did nothing to lighten other aspects of the workers' load, nor did they write into the policy recommendations for additional staff.

By ignoring the problem of inadequate staffing the committee perpetuated the old barrier to effective service to the resident, in this case effective protection of their funds.

The second issue that was not addressed in the new policy was that of lack of residents' involvement in the decision-making processes which affect their daily lives.

The committee had concurred that all residents 
should be encouraged to maintain maximum control over their lives, yet continued to write policy without the residents' input or evaluation.

Problems involving lack of communication and coordination were addressed as the policy process proceeded. In the beginning these issues loomed over the proceedings, but by the middle and final phases of the policy-writing process, the barrier seemed almost eliminated. It is interesting to note that the agency's new drive to cooperate and coordinate caused a sixmonth delay in the Personal Incidental Fund policy release.

The agency's goal, to release the new comprehensive Guides which would help to better coordinate the organizations sub-units (also containining the new PIF policy and regulations) could not be completed until June of 1977. Thus the policy was involved in the development of better communication and coordination within the Public Welfare Division

The new policy in no way addressed the barrier of inadequately trained nursing home personnel. However, it was hoped that the information booklet that was written would be used as a training booklet at the facilities. Therefore this barrier to effective service remained intact. There was no mention of 
training of the nursing home staffs by the Public Welfare Division and no suggestion as to how staff personnel implement the new policy.

The new PIF policy did not concern itself with the lack of up-to-date Guides and memoranda at the disposal of the adult service workers, although during the policy writing process the Congregate Care Consultant endeavored to release and circulate all available materials.

The final barrier, conflicting regulations, was successfully eliminated by the new Personal Incidental Fund policy. There appear to be no conflicting regulations between the policy and any previously written policy. The policy was written in consideration of HEW, the Social Security Administration, other subunits of the Public Welfare Division and other state agencies.

Policy-making is not a rational process in general and the Personal Incidental Fund policy-making process demonstrated this. The rational process that begins with first identifying the problem then clarifying values and objectives; listing all possible ways to achieve goals; investigating the consequences; comparing consequences and finally choosing the ideal policy (lindblom 1968) was not operational for this situation. 
Rather, the Nursing Home Committee and Congregate Care Consultant reviewed and revised the policy in light of the political, financial, and value conflicts that constantly impinged upon the process.

The policy is pragmatic, not ideal. It is also utilitarian, created to ameliorate the immediate and most obvious issues and problems relative to the residents' funds. The strategy used in the development demonstrates disjointed incrementalism. It is the process most appropriate to our form of government. Its use displays an agreement that we trade the "ideal" process for the democratically-oriented process of incrementalism.

The latest policy to be released is obviously not the final word on protection and use of residents' Personal Incidental Funds. The end of the policy writing process is in reality just the beginning. Forthcoming evaluation and feedback will stimulate yet further changes .

It remains to be seen if in the future nursing home policy writers will learn from this policy process. 


\section{BIBLIOGRAPHY}

Arbuckle, Richard. Assistant Manager, Medical Assistance Unit, Public Welfare Division. Interview, 4 November 1976,10 February 1977.

Braybrook, David and Charles Lindblom. A Strategy of Decision: Policy as a Social process. New York: Free Press, 1963.

Brody, Elaine M. A Social Work Guide for Long-Term Care Facilities. Rockville, Maryland: U.S. Department of Health Education and Welfare, U.S. Government Printing Office, 1974.

Burbidge, Nita. Supervisor, Facility Certification, Medical Assistance Unit, Public Welfare

Division. Interview, 4 November 1976.

Dodge, Robert. Supervisor, Adult Services, West Portland Branch, Public Welfare Division. Interview, 20 April 1977.

Epstein, Abraham. The Challenge of the Aged. New York: Macy-Masius, Vanguard Press, 1928.

Fay, Alice Murray, Cathy Hansbough, Virginia Irby, and John Wright. Adult Service Caseworkers, East Portland Branch, Public Welfare Division. Interview, 11 February 1977.

Gilbert, Neil and Harry Specht. Dimensions of Social Welfare Policy. Englewood Cliffs, New Jersey: Prentice Hall, 1974 .

Gray, S. B. "O.A.A. Recipients in 1965: Financial Circumstances." Welfare Review, Vol. 7, No. 4, 1969, pp. 13-18.

Greenfield, Margaret. Medicare and Medicaid. Barkeley, California: Institute of Government Studies, University of California, 1968.

Hall, Richard. Organizations: Structure and Process. Englewood Cliffs, New Jersey: Prentice Hall, 1970 . 
Hawes, Janice. "Personal Incidental Fund Account Audit Pilot Project." East Portland Branch, Public Welfare Division, 1977. (Mimeographed)

Jones, Charles 0 . An Introduction to the Study of Public Policy. Belmont, California: Duxbury Press, 1970 .

Kosberg, J. J. "The Nursing Home: A Social Work Paradox." Social Work, Vol. 18, No. 2, 1973, pp. 104-10.

Lemke, Marty, M.S.W. Social Worker, Columbia Manor Nursing Home. Interview, 5 May 1977.

Lindblom, Charles. The Policy-Making Process. Englewood Cliffs, New Jersey: Prentice Hall, 1968.

Marmon, Theodore. The Politics of Medicare. Chicago: Aldine Publishing Company, 1973.

Marquis, Charles E. Supervisor, Medical Independent Professional Review Team, Medical Assistance Unit, Public Welfare Division. Interview, 4 November, 1977.

Meyer, Robert J. Medicare. Bryn Mawr, Pennsylvania: McCahan Foundation, 1970.

Pincus, A. "The Definition and Measurement of the Institutional Environment in Homes for the Aged." Gerontologist, Vol. 8, No. 3, 1968, pp. 207-10.

Richard, John. Executive Vice President, Oregon Health Care Association. Interview, 23 January 1977.

Rosengren, William R. and Mark Lefton (Eds.). organizations and Clients: Essays in the Sociology of Service. Columbus, ohio: Charles Merrill Publishing Company, 1970.

Rothman, Jack. Planning and Organizing for Social Change: Action Principles from Social Science Research. New York: Columbia University Press, 1974 . 
Stevens, Robert and Rosemary Stevens. Welfare Medicine in America: A Case Study of Medicaid. New York: Free Press, 1974 .

Swarthout, Marilee. Nursing Home Administrator, St. Jude's Home, Sandy, Oregon. Interview, 20 April 1977.

U.S. Advisory Commission on Intergovernmental Relations Intergovernmental Problems in Medicaid. A Commission Report, i960.

U.S. Code of Federal Regulations. 45 CFR, part 201.0, revised, October 1976.

U.S. General Accounting Office. "Need to More Consistently Reimburse Health Facilities Under Medicare and Medicaid." Report to Congress, Department of Health, Education and Welfare, 1974.

White, Floyd. Supervisor, Medical Utilization, Public Welfare Division. Interview, 4 November 1976.

White, Leonard. Introduction to the Study of Public Administration. New York: Macmillan, 1948.

Williams, Corrine. Congregate Care Consultant, Adult Services Unit, Public Welfare Division. Interview, 12 October 1976 . 
APPENDIX A 
WHAT IS A PERSONAL INCIDENTAL FUND (PIF)?

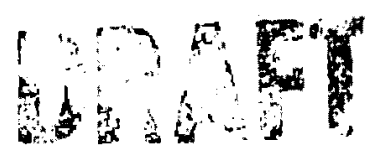

Every resident of a nursing home facility in Oregon who is eligible for Medicaid (Title XIX, Oregon Medical Assistance) is entitled to receive a monthly amount for clothing and personal needs.

WHERE DOES THE PERSONAL INCIDENTAL MONEY COME FROM:

This money can come from the resident's own benefits through a private pension, Social Security, Supplemental Security Income, Public Welfare Division, Veteran's Benefits or private income.

HOW MUCH MONEY DOES THE RESIDENT RECEIVE?

The resident will usually receive $\$ 25$. However, if the resident is purchasing Yedicare - Part B - insurance, that cost will be deducted from the $\$ 25$ received Erom Social Security.

CAN THE RESIDENT SAVE THIS MONEY?

Yes. However, the resident is encouraged to spend the money on $i$ tems and services which will contribute to his/her comfort and well-being while in the nursing home. HOW MUCH MONEY CAN THE RESIDENT RETAIN?

The resident can accumulate up to $\$ 1500$ in reserve resources. When that amount is reached, he/she becomes ineligible for Medicaid (Oregon Medical Assistance) until the excess monies are utilized.

WHY IS MANAGEMENT NEEDED?

These procedures have been developed to protect both the resident's monies and the manager of the PIFs. Monitoring of management responsibilities is required to assure protection of the resident's interests. Although residents are encouraged to participate as much as possible in spending their funds, facilities usually limit the amount of money which can be kept in the residents' rooms. Such rules necessitate the entrustment of larger sums of money to a relative, friend or nursing home administrator for safe keeping, and an accounting for disbursements. Cour ippointed guardians or conservators may also assume this responsibility.

"הĩO CAL HELP THE RESIDENT MANAGE HIS PERSONAL INCIDENTAL FUND?

All of us--the Adult Service Worker, the nursing home staff. But the best people in the world are those who are the patient's relatives and friends.

WHY ARE RELATIVES AND FRIENDS BEING ASKED TO HELP?

We believe that relatives and friends who care personally about the resident are the best qualified to understand their needs and desires.

HOW CAN RELATIVES, FRIENDS OR NURSING HOMES HELP?

When the resident or Adult Service Worker requests assistance on behalf of the resident, acceptance of management of the resident's Personal Incidental Funds can be an important service to the resident.

WHAT IS MEANT BY MANAGEMENT?

MANAGEMENT is holding, depositing, helping to properly spend, and accounting for deposits and expenditures of a resident's PIF monies. This may be for a short period or over a long time. (At time of death these funds become part of the resident's estate.) 
HOW DOES THIS ALL WORK?

Page 2.

The Public Welfare Division has written a set of procedure's that will help to

protect the residents' PIF. Working together we can all see that the job gets done.

IF THE RESIDENT DELEGATES RESPONSIBILITY OR MANAGEMENT IS REQUESTED ON BEHALF OF THE RESIDENT

WHO under the policy has responsibility: FOR what will they be responsible:

$\underline{\text { Resident }}$

PIF Manager

(Relative-Friend-Nursing Home Administrator)
1. To designate responsibility by signing Client Delegation for Management of Funds.

1. To accept responsibility by signing Assumption of Responsibility for Management of Client's Funds.

2. To save receipts and sales slips for three years.

3. To deposit funds in excess of $\$ 75$ into an interest bearing account. Amounts less than $\$ 75$ should be retained in a safe place or petty cash account. At the delegate's discretion, an interest-bearing account may be opened for amounts less than $\$ 75$.

4. To keep a simple record of income received and purchases made on the Resident Accounting Record; to give it to the resident and a copy to the Adult Service Worker every 3 months.

5. To contact the Adult Service Worker before making a single purchase of $\$ 50$ or more.

6. To use the available material on the AllInclusive Rate from the Nursing Home Guide as a reference when questions arise regarding charges to PIFs.

1. To contact potential PIF Managers for the resident and to fully explain the requirements for managing the Resident's Personal Incidental Funds.

2. To monitor the Resident Account Record at least every six months.

3. When needed, the Adult Service Worker shall obtain a statement from the physician concerning the client capability to manage own funds.

4. To review PIF accounts and the appropriate transfer of monies at the time a resident is moved from a facility, or is deceased.

\section{SLGGESTIONS FOR SPENDING PIFS}

PIFs are to be used for the personal needs of the resident. These include items such as clothing, tobacco, special toilet articles or other day-to-day incidentals. PIFs should not be used for basic materials, tools, activities or programs which the facility has the responsibility to provide.

The following is a list of some ways residents in nursing homes might be encouraged to utilize their personal funds. The list was compiled to assist you in bringing the resident increased opportunities for enjoyment and enrichment of daily living experiences within the nursing home set'ing. He/she should be encouraged to choose 
from a variety of special events offered on the basis of individual past interests, employment, skills, training and current needs. Such opportunities can promote ........ more independence and feelings of self-worth through stimulating derision-making on the part of the resident.

1. Special equipment and resources for individual musical enjoyment or auditory perceptions: earphones, tapes, records. Earphones enhance listening to T.V. or the radio or records without disturbing others close by. (Earphone sets may be obtained on a loan basis for blind persons along with "talking records" through the State Library.)

2. Special games with large print or numerals or parts not ordinarily expected to be available in the facilities. (A good selection should be provided by by nursing homes for individual/group stimulation in physical, mental. social and emotional areas.)

3. Special tools and materials for unusual hobbies, advanced crafts and woodworking, e.g., tying flies, carving, arts, gardening, birdwatching, etc. bevond introductory or routine occupational therapy materials.

4. Membership and participation costs in special organizations and service clubs: RSVP, Gray Panthers, Senior Centers, Church and Veteran groups, political party activities, drama clubs, pen pal clubs, etc.

5. Mailing correspondence or newsletters to others.

6. Participation in "employee of the month" recognition project through Residential Councils.

7. Membership in resident film club (renting movies on a regular basis).

8. Making long distance telephone calls to relatives and friends.

9. Owning and operating ham/citizen band radios.

10. For transportation* (when facility has no vehicle or transportation volunteers) involved with special outings:

to Senior Centers for recreation programs

to nutrition centers for meals and social interchange

as volunteers outside the facility

swimming and other games/sports such as fishing, boating

attending movies, concerts, sporting events

shopping trips

recreation trips, excursions

political and community meetings, working on election boards.

11. Private telephones for residents who wish to be a telephone reassurance volunteer or to maintain closer contact with friends and relatives.

12. Having guests to dinner at nursing home.

13. Having one's picture taken.

14. Participating in cocktail hour or Sherry Hours, or "Men's Night" or "Women's Night" playing cards with special refreshments and prizes.

15. Buying items from shopping cart (provided by Residents' Council or a service group or department store): everything from fresh fruit and candies to magazines, toys, miscellaneous clothing, lipstick, mirrors, toilet articles.

16. Purchasing miscellaneous medical items when PWD funds are exhausted and there appears to be no other means of the resident getting what he needs. The Adult. Service Worker should be consulted before medical items are purchased out of the resident's PIF.

*NOTE: some wheelchair clients can travel by taxi and reduce costs by traveling together. 


\begin{tabular}{|c|c|c|c|}
\hline PROISRAY & BRAMCH & CASE RUMBER & $\begin{array}{l}\text { HORKER } \\
1.0 .\end{array}$ \\
\hline \multicolumn{3}{|c|}{ CASE HAHE } & $\begin{array}{c}F \| E \\
11\end{array}$ \\
\hline
\end{tabular}

The Public Welfare Division has established a procedure for protection of property of those individuals who receive benefits through this agency. This form is to be used for the protection of the client's Personal Incidental Funds by Adult Service Workers, PWD, under ORS Chapter 411.

I accept the responsibility for handling and accounting for the Personal Incidental Funds of

I agree to keep a complete record of income and expenditures for the above named person, including sales slips and receipts for amounts spent, in conformance with the current PWD Guidelines. I will provide the account record (PID 713) to the client and a duplicate to the Adult Services PWD Worker at least once every three months, and retain the sales slips and receipts for auditing purposes.

I will contact the Adult Service Worker before making any single expenditure of $\$ 50$ or more at any one time.

When the accumulated Personal Incidental Funds for the PWD client exceeds the sum of $\$ 75$, I will deposit the money in trust for

in an interest-bearing account. The Adult Services Worker will be notified of the name of the bank, its address, and the trust account number at the time of the next quarterly report.

(Delegate's Signature) (Date)

Address

Telephone

Relationship to client:

Relative $\square\left(\frac{}{\text { (Specify) }}\right)$, $\square$ Friend, $\square$ Representative Payee,

$\square$ Facilicy Administrator, $\square$ Power of Attorney.

PLENSE NOmE: Failure to comply with the above agreement may constitute grounis for legal action for misuse of clients' funds, and the initiation of guardianship proceedings for the protection of the clients' properties.

Distribution:

White: Delegate Retains

Pink: Case File 
APPENDIX B 


\section{Department of Human Resources \\ PUBLIC WELFARE DIVISION}

PUBLIC SERVICE BUILDING, SALEM, OREGON 97310 PHONE 378-3716

client's Name

Dear :

The Public Welfare Division is calling on you as a person who may be interested in managing the Personal Incidental Fund allowance a nursing home resident receives every month in case the person is unable to do this for him/herself.

Because there have been major problems involving abuse of patients' personal funds throughsut the United States, there have be-n established new policies that will help to monitor and protect these funds. Possibly with your help, we hope that these funds can be managed to the best interest of your relative or friend under the newly developed policy. An important result of your sharing in this task could be a strengthening of the bond beween you and your relative or friend and special attention given to utilizing the nonies in more meaningful ways on behalf of the client.

'our relative or friend's Adult Service Worker will be available to inform and guide you :oncerning requirements. Some of the procedures required are the following:

1. The patient may sign the Delegation of Responsibility asking another person to assume responsibility for managing his/her Personal Incidental Funds; or, in some cases, the client's Adult Service Worker may ask the physician to complete a statement regarding the Client's Capacity to Manage Funds (PWD 544). If management needs to be delegated to another person, you may have the opportunity to handle and account for these monies.

2. If you accept responsibility for managing PIF monies for a client, you will be expected to:

a. Keep a simple record of your purchases;

b. Keep all sales slips and receipts for three years;

c. Before making a purchase of $\$ 50$ or more, contact the Adult Service Worker;

d. If the patient's funds accumulate to more than $\$ 75$ to place the excess in an interest bearing trust account in Oregon.

2 appreciate the possibility of your interest and willingness to be of service to sur relative or friend. These new responsibilities will require time and record zeping. These procedures offer protection for both the client's property as well as or those who assume responsibility for helping to manage these monies.

you are interested in pursuing this matter or need further information, please conict me.

\section{Sincerely,}

Name-Adult Service Worker

Telephone

Branch Address 
APPENDIX C 


\section{History of the PIF}

With the inception of the historic Social Security legisletion of 1935 , Dregon, along with ather states, began to recelve federal funds to aid older reaidents. Benefita were provided to eligible elderly poor, who became old Age Assiatance recipients, and recelved payment directly from the State. Old Age Absiatence recipiente who were Nursing Home residente paid the facilitieg directly for their care and kept a amall amount for their personal uee.

The direct payment aystem was ueed until 1956 when the State began to provide a broad range of medical services for recipients in all federally aided assistance categories. The complex new syatem included a partial payment to the Nursing Home (vendor) and partial payment to the patient. The patients were informed of the pre-established amount of money they would be allowed to keep for their personel incidental use. At this time, there were no written regulatione or procedures that directed the public assiatance worker or the mirsing hame staff in helping the patients spend, manage, or safeguard their money.

By 1959, the complex aystem was changed to a direct billing system, in which the nursing homes bill the State directly and the State pays for the care of the petiente directly. At this time the amount allotted for peraonal incidental clathing funds varied fram $\$ 3$ to 87 per month. This new system did not include any regulatory measures to protect the patienta' funds.

The Oregon Medicaid program created under the 1965, Title XIX of the Social Security Act provided coverage for all medically needy OAA recipients. This included nursing home petients. The legislation required that client income (Social Security, Pension, Property Income) be first applied to their personel needs; the balance was used to pay for their medical needs and nursing hame care. Oregon eatablished the amount of money that the patient would be allowed to keep for their personal needs at $\$ 15$ a month. At this time, the State developed its first regulations for protection and management of the patients' personal incidental funds. In their 1969 Dregon State Public telfare Division Agreement for Skilled Nuraing Home participation in the Title XIX program, it was established that the 5NF was responaible for maintaining an account of each patient's personal funde, and permitting a PWD audit of the accounts.

In mid-1974, the anount of PIF monies allotted to nursing home patienta was raised to \$25. At approximately this time the Medical Aasiatance Unit of the Public uelfare Diviaion was directed to include in their area of responsiblilty the PIF, through their already eatabliahed Medical Independent Review Team" system.

Both the Adult Service Section and the Medical Unit of PuD became auare of the need for policy to protect these monies for the client. Specific procedures and farms were published in the Vendor Guide for Skilled Nursing Facilities in 1975 under the revised rule five, part E, items 1, 2, 3. These requirementa were extended to Intermediate Care Facilities in 1976. With these requirements expectations were established as to what items and aervices were to be provided by the facility and what could be properly cherged to the patient's PIF. 
The facilities were also given proper procedurea for the managenent, accounting and banking of the patient's PIF.

The baeic outline of the State's philosophy and policy for protecting the patients' money was emerging. Unfortumately, exceptiona were made to the general rules at both the branch and the State levels and 1t became obvious that the policy meeded enforcement and amplification. Responding to this the Plid began a serles of pollcy development meetings that culninated in the net reguletions that become effective March 1 , 1977. 


\section{CONTROS DUER PERSCNAL FLNDS \\ OF MEDICAID PATIENTS IN MLRSING HOMES}

S1x Major National Problene

1. The facility policles and procedures for adequately accounting for patients' monles are elther weak or non-existent. Poor accounting techniques are enployed such as lack of receipting for credite to the patients, no quarterly accountability, mixing of general funde with the patient funds.

2. Shortages between patient ledger balances and bank accounts.

3. Inappropriate charging of patients far medical aupplies and aervices.

4. Retaining funde of deceased and trengferred patients

5. Retaining intereat earned on petient funds and other 1rregularitiea Imolving interest.

6. The use of patient funds to pay operating expenses. 
APPENDIX D 
ADULT SERVICES

November 22,1976

Protective Services

304-C

CONTENT :

Personal Incidental Funds

For carrying out responsibilities delegated to the Public Welfare Division to prevent the wasting, abuse or fraudulent use of clients' Clothing and Personal Incidental Funds, Adult Service Workers are required to observe the following procedures.

Delegation of Responsibility by Client

If the client wisheis to delegate responsibility for managing his/her clothing and Personal Incidental Funds to another individual such as a relative, friend, 'facility/residence manager, or representative payee, PWD (1)* should be completed and signed by the client for inclusion in the service record. (See PWD (1).)

Physician's Statement of Medical Incapacity

If the client is incapable of managing his/her Clothing and Personal Incidental Funds or of delegating responsibility for such management, the Adult Service Worker shall send PWD (ll)* to the attending physician for consideration after having completed the section including the client's name, address and age. If the physician attests to the client's inability to manage his/her funds according to the definition on the form, the Adult Service Worker should seek a relative, friend, facility/ residence manager, representative payee or foster parent willing to assume this responsibility'. In cases when guardianships, conservatorships or representative payee arrangements have already been established or appear desirable, PWD (1I) will not be necessary as proper documentation should already be in the service record, or procedures for establishing such arrangements have already been defined. (See PWD (11).)

Assumption of Responsibility by Delegate

1. PWD Guidelines and Accounting Form (713)

When agreement has been reached with an appropriate individual/ facility willing to assume the responsibility for management of a client's Clothing and Personal Incidental Funds, PWD (III)* should be completed in duplicate after the Adult Service Worker has explained the use of the attached Guidelines and PWD 713. The PWD Guidelines describe the items which are to be included in the rates

* Numbers for forms herein referred to as (1), (11), (1ll) will be requested. Final material will contain these forms. 
paid the provider for room, board and necessary care, and exceptions to that agreement which may be charged to the client's personal funds. Instructions should also be given to the delegate concerning PWD 713 for the duarteriy accounting to be sent to both the clion the Adult service worker, the necessity for retaining receipts and sales slips for monitoring purposes, and the desirability of the delegate communicating promptly with the Workers should questions arise over verbal billings to these funds by providers or related matters.

A signed copy of PWD (III) should be retained by the delegate, another signed copy should be included in the service record, and a copy also given to the facility/residence manager for that organization's records and convenience if that person is not the delegate. This procedure (obtaining signed PWD (III)s and completed PWD 713 s every three months) applies to all clients living in residentlal/institutional settings -- including clients for whom guardianships, conservatorships and representative payees have been appointed. It should assist delegates to discriminate between appropriate and inappropriate charges for drugs', services and other items about which there is no confusion. When a nursing home assumes responsibility for managing the Clothing and Personal Incidental Funds of a resident, it will already have access to information on appropriate charges and the required accounting system from the Nursing Home Guides. A copy of the PWD 713 should still be sent by the facility to the Adult Service Worker at quarterly intervals for monitoring purposes.

2. Expenditures of $\$ 25$ or More

The stipulation that the delegate, including nursing home management, shall contact the Adult Service Worker before making a single expenditure of $\$ 25$ or more Pequires that the Worker have some knowledge as to what kinds of expensive purchases will be in the best interest of the client. Such recommendations should also be documented in the Service record to be checked with purchases accounted for on PWD 713.

3. Interest-Bearing Savings Accounts for Funds of $\$ 75$ or More

The requirement for accumulated Clothing and Personal Incidental Funds of $\$ 75$ or more to be deposited in an interest-bearing account is in keeping with policy established by the Social Security Administration ( $\mathrm{CM}$ Sections $3115-3117$ ) and applies to all clients for whom responsibility has been delegated for managing their funds (including those accounts handled by nursing homes.) The name, address, bank account number and balance should be included on the quarterly PWD 713 accounting.

4. Inappropriate Charges to Clients' Clothing and Personal Incidental Funds

When improper charges to a client's funds are discovered by the Adult Service Worker, the matter should be brought to the delegate's attention immediately and repayment requested. Management should become involved at the Branch level when the Worker's efforts 
prove ineffective. All attempts for remedying inappropriate charges should be documented in writing and should include the amounts charged, the date on which it was recorded, the alleged purpose and person(s) involved. Failure to remedy such misuse or possible fraudulent use of a client's funds can ensue in one or more of the following courses of action by the Branch, depending upon the nature and extent of the improper charges:

(1) nullification of the current arrangement for management of the client's funds and a new agreement undertaken with another delegate by the Adult Service Worker or guardianship procedures initiated;

(2) referral of the case to the Medical Utilization Unit when a nursing home is involved with inappropriate charges (Volume VIII, 8455) so that recovery steps may be taken in accordance with the agency-provider agreement ;

(3) referral to Legal Aid for recovery purposes on behalf of the client or to the Social Security Administration for investigation and possible criminal prosecution by the Department of Justice, or both. 
PWD (1)

This form is to be used for the protection of the clients' Personal Incidental Funds by Adult Services Workers, Public Welfare Division, under ORS Chapter 411 .

DELEGATION OF RESPONSIBILITY FOR MANAGING PERSONAL INCIDENTAL FUNDS BY CLIENT OF PWD

I, hereby delegate the respon-

sibility for handling and accounting for my Personal Incidental

Funds to (Name of Individual or Facility) at

I understand that an Account Record will be given to me at least every three months by the above party, and a duplicate given to my Adult Services Worker, PWD. 
This form is to be used for the protection of the client's Personal Incidental Funds by Adult Service Workers, Public Welfare Division, under ORS Chapter 411 .

PHYSICIAN'S STATEMENT REGARDING PATIENT'S INCAPACITY TO MANAGE PERSONAL INCIDENTAL FUNDS

Patient's Name

Patient's Address

Date of Birth

A person is able to manage personal incidental funds if that person can direct the use of such monies for that person's own well-being and to protect that person's interest.

1. In your opinion, is the patient able to manage personal incidental funds in the patient's own interest?

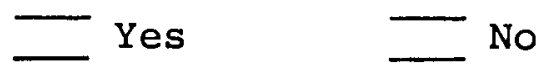

2. Describe the findings that lead to this conclusion:

3. On what date did you last examine patient?

4. What is the diagnosis of the patient's present condition?

5. Do you expect this inability to manage funds to continue indefinitely?

- Yes No Undetermined

6. If NO, when do you expect the patient's ability to be restored?

7. Remarks

I hereby certify that the above statements and answers are true to my best information, knowledge and belief.

8. Physician's Signature City Date 
PWD (111)

This form is to be used for the protection of the clients' Personal Incidental Funds by Adult Services Workers, Public Welfare Division, under ORS Chapter 411.

AGREEMENT FOR THE ASSUMPTION OF RESPONSIBILITY FOR HANDLING AND ACCOUNTING FOR PERSONAL INCIDENTAL FUNDS OF PWD CLIENT BY DELEGATE

I hereby accept the responsibility for handling and accounting for the Personal Incidental Funds of PWD client I agree to keep a complete record of income and expenditures for the above named person, including sales slips and receipts for amounts spent, in conformance with the attached PWD Guidelines of which I have current copy. I'will provide the account record (PWD 713) to the client and a duplicate to the Adult Services PWD Worker at least once every three months.

I will contact the Adult Service Worker before making any single expenditure of $\$ 25$ or more at any one time.

When the accumulated Personal Incidental Funds for the PWD client reaches the sum of $\$ 75$ or more, I will deposit the money in a joint, interest-bearing bank account, keeping nò more than $\$ 25$ on hand as a petty cash fund. The Adult Services Worker will be notified of the name of the bank, its address, and the account number at the time of the next quarterly report.

(Delegate)

\section{Address}

(Date)

Telephone

Relationship to Client:

Relative ), Friend - Representative Payee

Conservator , Guardian , Facility Administrator

Power of Attorney

PLEASE NOTE: Failure to comply with the above agreement may consititute grounds for legal action for misuse of clients' funds, and the initiation of guardianship proceedings for the protection of the clients' properties. 
APPENDIX E 
PWD 542: Assumption of Responsibility for Management of client Funds

1. Rules and Guidelines in the Nursing Home Guides, Including PWD 713

When an appropriate individual/facility has expressed willingness to assume responsibility for managing a client's clothing and Personal Incidental Funds, the worker must carefully explain the requirements outlined on PWD 542 and the attached materials. The PWD rules in the Nursing Home Guides describe the type of items which are included in the rates paid the provider for room, board and necessary care and describe the type of items that are not included in the rates paid the provider for room, board and necessary care and describe the type of items that are not included in the rate which may be charged to the patient's personal funds. Instruction should also be given to the delegate for completing PWD 713 as the quarterly accounting. The form should be kept in triplicate: the original should be retained by the delegate, the yellow copy given to the client, and the pink copy sent to the Adult Services worker for filing in the Service record. Receipts and sales slips for auditing purposes should be retained by the delegate. Also the delegate should be informed of the desirability to communicate promptly with the Workers should questions arise over verbal billings to these funds by providers or related matters.

The PWD 542 must be signed in duplicate: the original must be retained by the delegate, and the duplicate must be included in the service record. This procedure (completion of PWD 542 and quarterly copies of PWD $713 \mathrm{~s}$ being given to the client and Adult Services worker) applies to all clients living in residential/ institutional settings -- including clients for whom representative payees have been appointed. The procedure should assist delegates to discriminate between appropriate and inappropriate charges for drugs, services and other items. When a nursing home assumes responsibility for managing clothing and Personal Incidental Funds of a resident, it will already have access to information on appropriate charges and the required accounting system from the Nursing Home Guides. A copy of the PWD 713 must still be given by the facility to the client and to the Adult Service Worker at quarterly intervals for monitoring at the time of Level of Care review. Copies of PWD 713 will be filed in the service record.

2. Expenditures of $\$ 50$ or More

The stipulation that the delegate, including nursing home management; must contact the Adult Service Worker before making a single item expenditure of $\$ 50$ or more requires that the worker have some knowas to what kinds of expensive purchases will be in the best interest of the client. Such purchases must also be documented in the service Record and cross-checked with the purchases accounted for on PWD 713 at the time of Level-of care review. 
3. Interest-Bearing Accounts for Funds of $\$ 75$ or More

The requirement that accumulated clothing and Personal Incidental Funds exceeding $\$ 75$ be deposited in a interest-bearing account is in keeping with policy established by the Social Security Administration* and applies to all clients for whom responsibility has been delegated for managing their funds (including those accounts llandled be nursing homes.) At the discretion of the delegate, accounts may by opened for amounts of $\$ 75$ or less, depending upon the individual client's clothing and personal needs. The name, address, bank aocount number and balance of such accounts must be included on the quarterly PWD 713 accounting form.

4. Inappropriate Charges to Clients' Clothing and Personal Incielental Funds

When improper charges to a client's funds are discovered by the Adult Service Worker, the matter must be brought to the delegate's attention immediately and repayment requested. Management must become involved at the Branch level when the worker's efforts prove ineffective. All attempts for remedying inappropriate charges must be documented in writing and will include the anounts cliarged, the date on which it was recorded, the alleged purpose and person(s) involved. Failure to remedy such misuse or possible fraudulent use of a client's funds can ensue in one or more of the following courses of action by the Branch, depending upon the nature and textell of the improper charges:

(1) nullification of the current arrangement for management of the client's funds and a new agreement undertaken with another delegate by the Adult Service Worker or guardianslip procedures initiated;

(2) referral of the case to the Medical Utilization Unit when a nursing home is involved with inappropriate charges to clients or others* so that recovery steps may be taken in accordance with the agency-provider agreement;

(3) referral to Legal Aid or the District attorney for recovery purposes on behalf of the clients or others, or to the Social Security Administration for investigation and possible criminal prosecution by the Department of Justice.***

SSA Claims Manual, Section $311^{\prime}, 3117$

See PWD Manual VIII, 8455

SSA Claims Manual Section 7502-3,7506.4,7509.5 
The Public Welfare Division has established a procedure for protection if property of those individuals who receive benefits through this agency. chis form is to be used for the protection of the client's Personal Incidental Funds by Adult Service Workers, PWD, under ORS Chapter 411.

: accept the responsibility for handling and accounting for the personal incidental Funds of

: agree to keep a complete record of income and expenditures for the above lamed person, including sales slips and receipts for amounts spent, in :onformance with the current PWD Guidelines. I will provide the account :ecord (PWD 713) to the client and a duplicate to the Adult Services PWD lorker at least once every three months, and retain the sales slips and eceipts for auditing purposes.

will contact the Adult Service worker before making any single expendture of $\$ 50$ or more at any one time.

Then the accumulated Personal Incidental Funds for the FWD client exceeds :he sum of $\$ 75$, I will deposit the money in trust for.

in an interest-bearing account. The Adult services rorker will be notified of the name of the tank, its address, and the trust iccolnt number at the time of the next quarterly report.

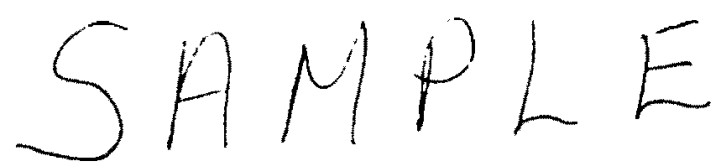

(Delegate's Signature) (Date)

Address

Telephone

relationship to client:

relative $\square\left(\overline{(s p e c i f y}^{\prime}\right), \square$ Friend, $\square$ pepresentative Payee,

口Facility Administrator, $\square$ Power of Attorney.

'LEASE NOTE: Failure to comply with the above agreement may constitute rounds for legal action for misuse of clients' funds, and the initiation if guardianship proceedings for the protection of the clients' properties.

Distribution:

White: Delegate Retains

Pink: Case File 


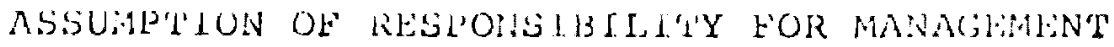 OF GILNT'S RERSONAT FUNDS}

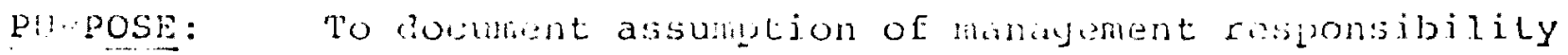
by dislegate.

WhO USES: Dologate assuming responsibility; Malt Survicas Wurker.

COMPlin'joN: Mault Services Wuker fills jn name of lWD client and lelationshjp of delegate to client. Delegate (uingletis nane, withiss, Leliphone numbor and date signed. 


\begin{tabular}{|c|c|c|c|}
\hline PROCRAM & BRANCH & CASE NUMBER & WORKER TO \\
\hline CASE NAY & & & FILE \\
\hline
\end{tabular}

This form is to be used for the protection of the clients' personal Incidental Funds by Adult Services borkers, Public Welfaro Division, under ORS Chapter 411.
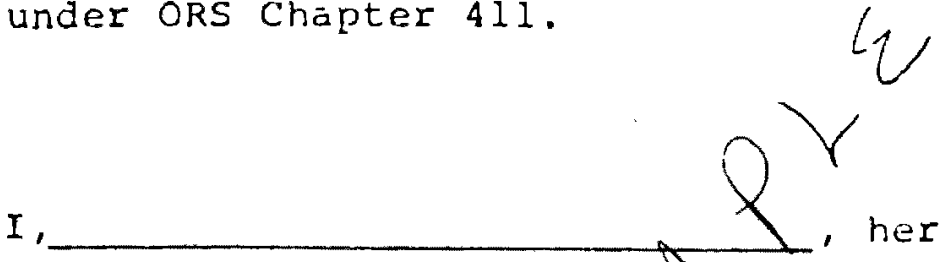

hereby delegate the responsibility

for handing and accountifor fory Personal Incidental Funds to:

(Name of Individual or factility) at

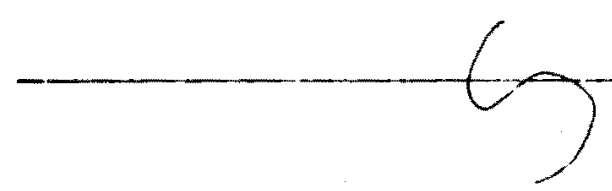

I understand that an Account Record will be given to me at least every three months by the above pirty, and a duplicate given to my Adult Services horker, PWD.

(Cliert's signature)
(Date)
$(\because$ incss)

Distribution:

White: Delegate

Yellow: Ciient

Pink: Case Record 


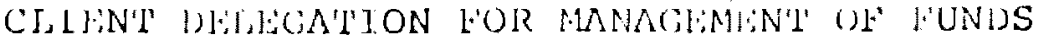

"URPOSE: TO assign responsibility for mamianment of funts by PWD client.

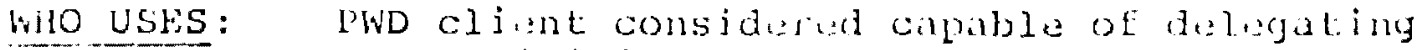
ressponsibility.

COMPLEIION: Adult Sinvices Worker completes name of pWo clinent, Delegate's name and aldress, and Aate signed; l'WD client signs name. 
This form is to be used for the protection of the client's porsonal Incidental Funds by Adult Service Workers, Public Welfare Division, under ORS Chapter 411 .

Patient's Name

Patient's Address

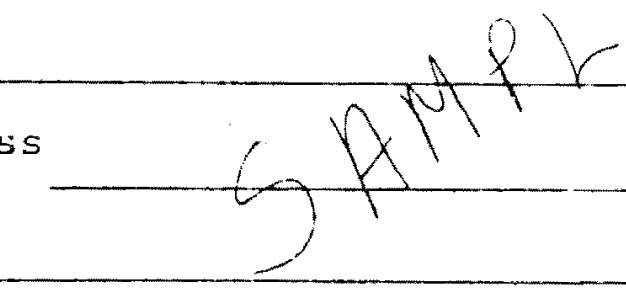
Date of Birth

A person is able to manage personal incidental funds if that purson can direct the use of such monies for that person's own well-being and to protect that person's interest.

1. In your opinion, is the patient able to managc personal inciaental funds in the patient's own interest:
$\square$ Yes
$\square$ No

2. Describe the findings that lead to this conclusion:

3. On what date did you last examine patient?

4. What is the diagnosis of the patient's present condition?

5. Do you expect this inability to manage runds to continue indefinitely?
$\square$ Yes
$\square$ No
Undetermincd

6. If No, when do you expect the patirnt's ability to be restcred?

7. Remarks:

8. Physiciar's Signature:

City Date 


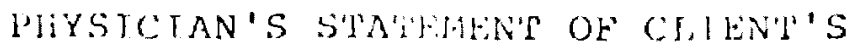 \\ CAPRELIY TOO IIANACSE FIJNDS}

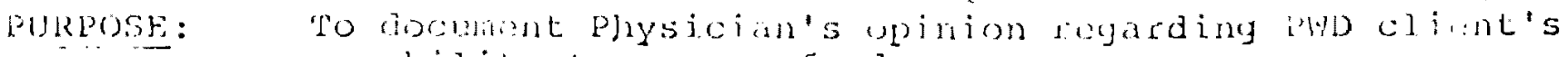
cupability to laridge rumls.

Who Usies: Ault sezvicos Workor roguests statement of physicjan when ciablidity in guostion.

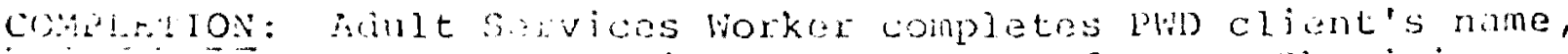
widrotas and birthdate at top of parge; physician com-

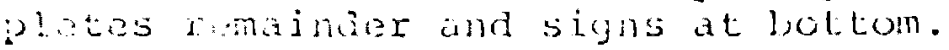




\section{PERSONAL FUINISS ACCOUNIING FURM}

Purpose: To account for mamagment of i'W clients' personal funds.

Who Uses: PWD Client, Client's Dolegate: Rolative, Friend or Designated Facility Personnel Authorized PWD Employaes

Completion: Delayate completes hoadings and balancos accounts. All entrizs initialled.

Delegate itemizes expenditures, or anounts given to relatives or clients, wilh recaipt of such funds being acknowleaged by initials in additional column. 
ADULT SERVICES

January 25, 1977

Protective Services

$304-1$

CONTENT :

Personal Incidental Funds

Adult Service workers are required to observe the following procedures for carrying out responsibilities delegated to the Public Welfare Division to prevent the wasting, abuse, or fraudulent use of clients* Clothing and personal Incidental Funds.

Definition of Management of Clients' Funds

The term management of clients' monies is used to include thr entrustment of funds to another person (for short or long duration), jroper expenditures of such, and regular accountings for either or both according to PWD Guidelines and PWD 713.

PWD 543: Client Delegation for Management of Funds

This form is to be used only when the client is considered capable of making the decision to delegate some responsibility for managing his/her personal monies. If the client wishes to delegate responsibility for managing his/her Clothing and Personal Incidental Funds to another indi-. vidual such as a relative, friend, provider, or representative payee, PWD 543 should be completed in triplicate and signed by the cilient. The delegate retains the original copy; the client the yeliow copy; the pink copy is to be filed in the Adult Service Record.

PWD 544: Physician's Statement of Client's Capacity to Manage Funds

If the client is thought incapable of managing his/her clothing and Personal Incidental Funds or of delegating responsibility for such management, the Adult Service worker shall send PWL 544 to the attending physician for consideration after having completed the section including the client's name, address ard age. If the physician attests to the client's inability to manage his/her funds according to the definition on the form, the Adult Service Worker should sesk a relative, friend, facility/residence manager, representative payee or foster parent willing to assume this responsibility. In cases when guardianships, conservators or representative payee ** arrancements have been established PID 544 will not be necessary because proper documentation should already be in the service recorl. 'Ihis pirysician's statement should be included in the Service record. Special payments when required for such physician services, ...uy be made from Administrative Medical costs** for the purpose of casework planning.

PWD clients living in nursing humes, homes for aged, group care homes, in adult foster care or other situations requiring protective services.

See PWD Manual III, $304-B$ and $304-E$

Set PWD Manual VIII, Section $81 \% 2.2$. 